\title{
Tire Development for Effective Transportation and Utilization of Used Tires \\ CRADA 01-N044, Final Report
}

\author{
DOE/NETL-2004/1204
}

\author{
Susan M. Maley
}

March 2004

U.S. Department of Energy

National Energy Technology Laboratory P.O. Box 880, 3610 Collins Ferry Road

Morgantown, WV 26507-0880

and

JANRT Tire Recycling Equipment

13211 Griffin Run

Carmel, IN 46033

Mary Ellen Corporation

Route 3, Box 98

Bridgeport, WV 26330

American Bituminous Power Partners, L.P.

P.O. Box 159

Grant Town, WV 26574
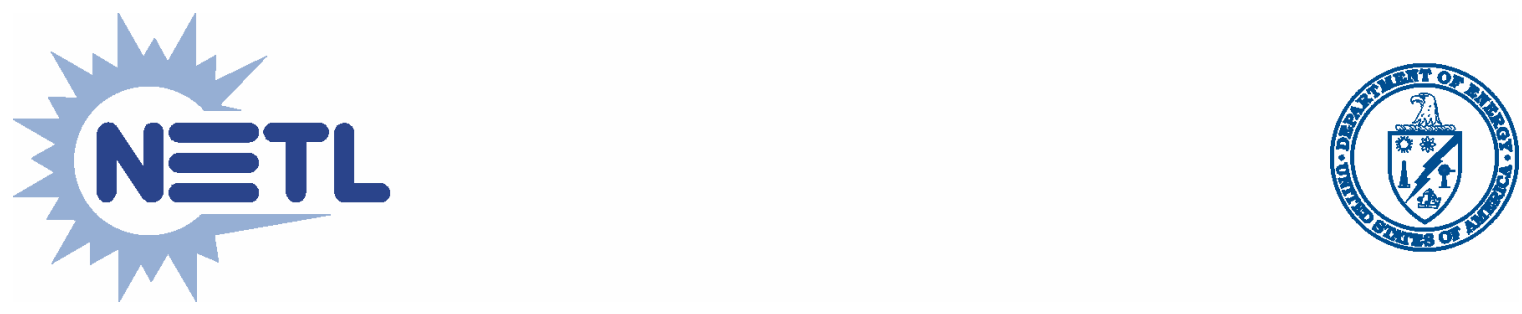


\section{Disclaimer}

This report was prepared as an account of work sponsored by an agency of the United States Government. Neither the United States Government nor any agency thereof, nor any of their employees, makes any warranty, express or implied, or assumes any legal liability or responsibility for the accuracy, completeness, or usefulness of any information, apparatus, product, or process disclosed, or represents that its use would not infringe privately owned rights. Reference therein to any specific commercial product, process, or service by trade name, trademark, manufacturer, or otherwise does not necessarily constitute or imply its endorsement, recommendation, or favoring by the United States Government or any agency thereof. The views and opinions of authors expressed therein do not necessarily state or reflect those of the United States Government or any agency thereof. 


\section{Contents}

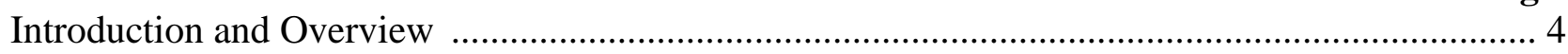

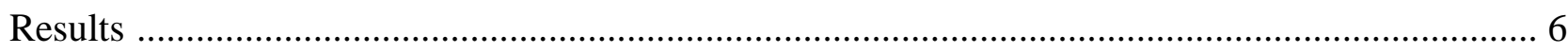

Design of the Mobile Tire Shredding Unit ..................................................................... 6

Economic Analysis on the Operation of the Mobile Unit ..................................................... 7

Outreach and Communication ......................................................................................... 7

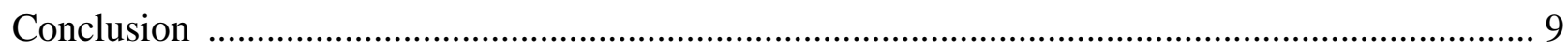

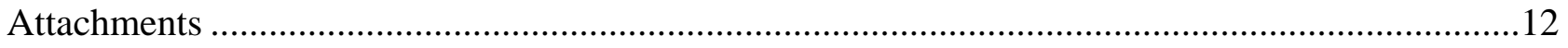

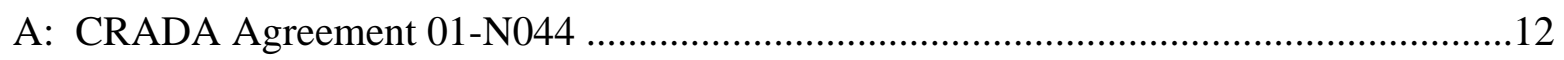

B: Presentations and Other Communication ……………..............................................2

Tires as a Fuel, Public Meeting Presentation, June 14, 2001 ..........................................27

Reasoning With Fear, Public Meeting Presentation, August 2, 2001 ..............................41

Lessons Learned From Grant Town, Internal Lessons-Learned Presentation,

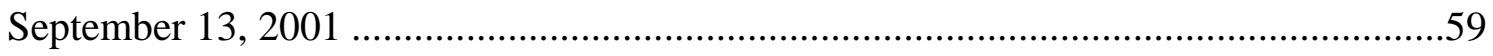

Production of Tire Derived Fuel: Use of a Mobile System as a Viable Economic Alternative, Conference Abstract and Presentation for 28th International Technical Conference on Coal Utilization and Fuel Systems, March 13, 2003 .68

Co-Firing Tire-Derived Fuel Advanced Combustion Systems, NETL Fact Sheet, 02/2003, Proj177.pmd

C: Tire Derived Fuel: Key Considerations for Power Generation and Industrial

Facilities, Susan Maley, National Energy Technology Laboratory, March 2004

\section{List of Figures}

1 Schematic of Mobile Tire Shredding Unit .10

2 General Economic Analysis of the Mobile Shredding Unit: Return on Investment Versus Tipping Fee and Hours of Daily Operation 


\section{Introduction and Overview}

Scrap tires represent a significant disposal and recycling challenge for the United States. Over 280 million tires are generated on an annual basis, and several states have large stockpiles or abandoned tire piles that are slated for remediation. While most states have programs to address the accumulation and generation of scrap tires, most of these states struggle with creating and sustaining recycling or beneficial end use markets.

One of the major issues with market development has been the costs associated with transporting and processing the tires into material for recycling or disposal. According to a report by the Rubber Manufactures Association tire-derived fuel (TDF) represents the largest market for scrap tires, and approximately 115 million tires were consumed in 2001 as TDF (U.S. Scrap Tire Markets, 2001, December 2002, www.rma.org/scraptires). This market is supported primarily by cement kilns, followed by various industries including companies that operate utility and industrial boilers. However the use of TDF has not increased and the amount of TDF used by boiler operators has declined.

Scrap tire markets are further supported by state programs through incentives or other funding mechanisms from the collection of fees or taxes. For utility and industrial boilers, TDF is used as a supplemental fuel because it's low cost and high heating value relative to coal. It has been demonstrated that the proper use of TDF can boost the efficiency of a suitable coal combustion system as well as lower the emissions from the unit. While TDF combustion is controversial in certain localities, many states have permitted facilities to use TDF fuel as well as whole tires. One way to make TDF readily available to suitable power generation facilities is to lower the costs associated with processing whole tires into the specific type of TDF needed for their system. The costs associated with transportation of whole tires, the energy intensive stationary tire processing equipment, and the transportation of the TDF to the power plant are a challenge in sustaining TDF markets.

NETL formed a cooperative research and development agreement (CRADA) to address both transportation and economic barriers to processing scrap tires with the end product being TDF for co-firing in suitable coal-fired power plants. This reports details the efforts by NETL and its CRADA partners to devise a potential solution to producing TDF material at reasonable costs. The efforts focused primarily on the creation of a mobile tire shredding unit. The envisioned benefits from this work were support of small business development, establishment of a local or regional market for TDF material, and sustaining the use of coal. In addition, efficiency and environmental performance would be enhanced for select power plants by incorporating the use of TDF as a supplemental fuel.

A CRADA was formed by NETL with JANRT Tire Recycling Equipment, LLC (formerly Tiger Equipment Company), Mary Ellen Trucking Company (MET), and American Bituminous Power Partners, L.P. The CRADA was originally an 18-month effort, initiated in February 2000, but was extended until February 2004. Both JANRT and Mary Ellen Trucking are minority-owned small businesses. NETL strategically brought these CRADA partners together to design, manufacture, and demonstrate a mobile tire shredder system. 
The original scope of work outlined for CRADA included four phases:

- Phase I-To develop detailed specifications and drawings for the mobile tire shredding system, develop a sampling plan and public relations plan for Grant Town Power Plant, and gather data on routing software for the system and pertinent permitting information from other facilities.

- Phase II-To focus on (1) sampling associated with the trial burn at Grant Town Power Plant to be conducted by American Bituminous Power Partners, (2) an economic analysis of operating the mobile system, (3) preparation for demonstration of the prototype system, and (4) development of a model for modifying air and ash permits for power plants capable of accepting TDF material.

- Phase III-Construction of the prototype system.

- Phase IV - A 9-month (minimum) demonstration of the mobile unit, where the Grant Town Power Plant agreed to purchase the TDF material from Mary Ellen Trucking for up to 18 months.

- Phase V-To conduct a CRADA evaluation.

NETL, with support from Parson's Engineering Support Services, would design the mobile tire shredder system. NETL would also lead or assist in the other activities outlined in the CRADA agreement. JANRT would assist in the design review, conduct an economic analysis, and manufacture one or two prototype systems at cost. Mary Ellen Trucking would also assist in the design review, purchase the mobile tire system from JANRT at cost, furnish the truck to operate the system, and develop a local market for tire disposal and demonstration of the prototype system. American Bituminous Power Partners would provide an outlet for the TDF material either though a trial burn or permit modification to accept TDF material at their 80-megawatt (MW) facility located in Grant Town, WV. Together these partners had the expertise and facilities to demonstrate the capability of this system to produce and transport TDF economically. The following outlines the intended contributions or in-kind services of the CRADA partners:

National Energy Technology Laboratory
JANRT Tire Recycling Equipment
Mary Ellen Trucking
American Bituminous Power Partners

$\begin{array}{lc}\text { Original } & \text { Actual } \\ \$ 235,000 & \$ 333,800 \\ \$ 159,189 & <\$ 50,000 \\ \$ 197,679 & <\$ 50,000 \\ \$ 60,000 & <\$ 50,000\end{array}$

The CRADA was not extended past February 2004 because of to lack of progress, lack of funds by the CRADA partners, changes in business focus, public opposition against Grant Town's interest in using TDF, and realignment of NETL's Combustion Technology Program. For these reasons, only a portion of the original scope was completed. The work completed included outreach activities, the conceptual and detailed mechanical design of the mobile tire shredding unit, economic analysis of operating the system, and a topical report on key consideration for cofiring TDF with coal. The remainder of this report details the completed work. 


\section{Results}

\section{Design of the Mobile Tire Shredding Unit}

NETL led the effort in conceptually designing and supporting the detailed mechanical design of the mobile tire shredding unit. Parsons Engineering Support Services developed the detailed mechanical design package with input from NETL and the CRADA partners. Parsons developed drawings sufficient for prototype construction, including specification of equipment, hydraulic power requirements, and connections to the truck's power systems. Figure 1 shows an overview of the system.

The unit was designed to slice, cut, and chop passenger vehicle tires into 1-inch chunks with wire remaining in the chunks. The unit was designed with the capability of processing two tires per minute and automatically conveying them into the bed of a large dump truck. The mobile unit would be mounted on a heavy duty trailer base and would be covered on all sides with the tires being fed from the back. The designed incorporated lever bars at the back of the trailer for loading the tires. Ease of loading permitted the process to be a one- or two-person operation, and minimized the lifting required by the operator to place the tires on the trailer.

The system was set up with two independently operated slicing machines to laterally slice the tires. A cutter bar was incorporated into the rotating machine to horizontally cut the tire into pieces. These tire pieces were conveyed to a hopper, which fed an oversized shredder that would reduce the tire pieces to an average size of 1-inch chunks. Wire was not removed from the tires, since this required additional equipment and was not thought to impact product quality if the TDF size was maintained at or near 1-inch x 1-inch.

The large dump truck was chosen to accept the processing of a large number of tires $(1,500$ to 2,000 processed tires). The large truck was also needed for its hydraulic system to power the mobile unit, and the unit was designed such that no or only minor modification of the hydraulic system would be needed. The large dump truck also provided a means to transport the TDF material to the power plant or some intermediate storage or accumulation facility.

The conceptual design of the ancillary systems (electrical and control systems) was developed by NETL. The detailed design of the ancillary systems was to be provided by JANRT in the form of design drawings or as built drawings. The electrical and control systems would automate the process and include safety features and fail-safe protocol. In addition to the control system for operating the unit, the use of routing software and basic business or invoicing capability was included in the overall conceptual design. No detailed designs were developed. 


\section{Economic Analysis on the Operation of the Mobile Unit}

Using the data generated from the detailed design of the mobile shredding unit, a consultant to JANRT developed an economic analysis of the unit to determine the profitability of the unit for a given range of the following parameters:

- $\quad$ Disposal fees (\$0.50 to \$2.50)

- $\quad$ Selling price of TDF ( $\$ 10$ to 20/ton of TDF)

- $\quad$ Number of tire processed in a day (0 to 800 tires/day)

- $\quad$ Cost of fuel (\$1.50 to \$2.00/gallon)

- $\quad$ Average distance traveled in a day (50 to 300 miles/day).

Other costs, such as maintenance, licenses, and registration were assumed. Since the parameters are highly variable, the potential profitability was also highly variable. However, within a realistic range of these values, the operation of the system is profitable if it is located within a reasonable distance from the scrap tire sources and the power plant or other end user. In most cases, income from selling TDF material covers the estimated maintenance costs of the mobile system.

This resulted in the tipping fee or disposal fee paid by the retailers to be primary source of income where a tipping fee of $\$ 1.50$ to $\$ 2.00$ /tire resulted in a reasonable profit margin needed to justify the approach. Tipping fees in this range are common throughout the United States.

Results of a general economic analysis are shown in Figure 2. Additional analysis would be required if a specific location and potential market were identified. A March 2003 presentation at the 28th International Technical Conference on Coal Utilization and Fuel System included results from using this tool. This presentation is provided in Attachment B. In general, the use of the mobile tire shredding system is more economical than the traditional process of transporting whole tires to stationary tire processing equipment, followed by transportation to the end user to produce wire in TDF.

\section{Outreach and Communication}

Numerous outreach activities were conduct in support of this CRADA and are provided in Attachment B. NETL participated in developing presentation materials for public meetings held by American Bituminous Power Partners to discuss Grant Town's interest in co-firing TDF with their low-rank coal. NETL also participated in these public meetings. Two public presentations were made followed by an internal lessons-learned presentation after opposition to TDF was voiced. The opposition was captured in several newspaper articles and petition describing the opposition that circulated through Senator Byrd's office. In response to this opposition, American Bituminous Power Partners withdrew their interest, and did not pursue permission from West Virginia Department of Environmental Protection to conduct a trial burn using TDF.

NETL continued other outreach activities, including the 2003 presentation at the 28th International Technical Conference on Coal Utilization and Fuel System in which the economic viability of the mobile tire unit was discussed. NETL also met with representatives of the 
Upgraded Coal Interest Group (UCIG) to discuss the project and identify alternative sites to using the TDF material. A fact sheet was prepared for the CRADA and issued in 2003.

NETL also developed a report on the key considerations for using TDF by power generation facilities and industrial boilers. Parsons assisted in developing a topical report, which included those things that must be factored into the decision to co-fire TDF with coal. This report included the permitting requirements that could reasonably be expected if existing permits were to be modified to include the use of TDF. This report is provided in Attachment C. 


\section{Conclusion}

The work completed through this CRADA has shown the potential of a mobile tire shredding unit to economically produce TDF and to provide an alterative low cost fuel to suitable coal-fired power systems. This novel system addresses the economic barriers by processing the tires at the retailer, thereby eliminating the costs associated with hauling whole tires. The equipment incorporated into the design allow for small 1-inch chunks of TDF to be produced in a timely fashion. The TDF can then be co-fired with coal in suitable combustion systems, such as a fluidized bed. Proper use of TDF has been shown to boost efficiency and reduce emissions from power generation systems, which is beneficial to coal utilization in existing power plants.

Since the original scope of work outlined in the CRADA could not be completed because of lack of progress by the CRADA members, the agreement was not extended beyond February 2004. The work completed included the detailed design of the mobile unit, a general economic analysis of the operating the system, and outreach activities. 


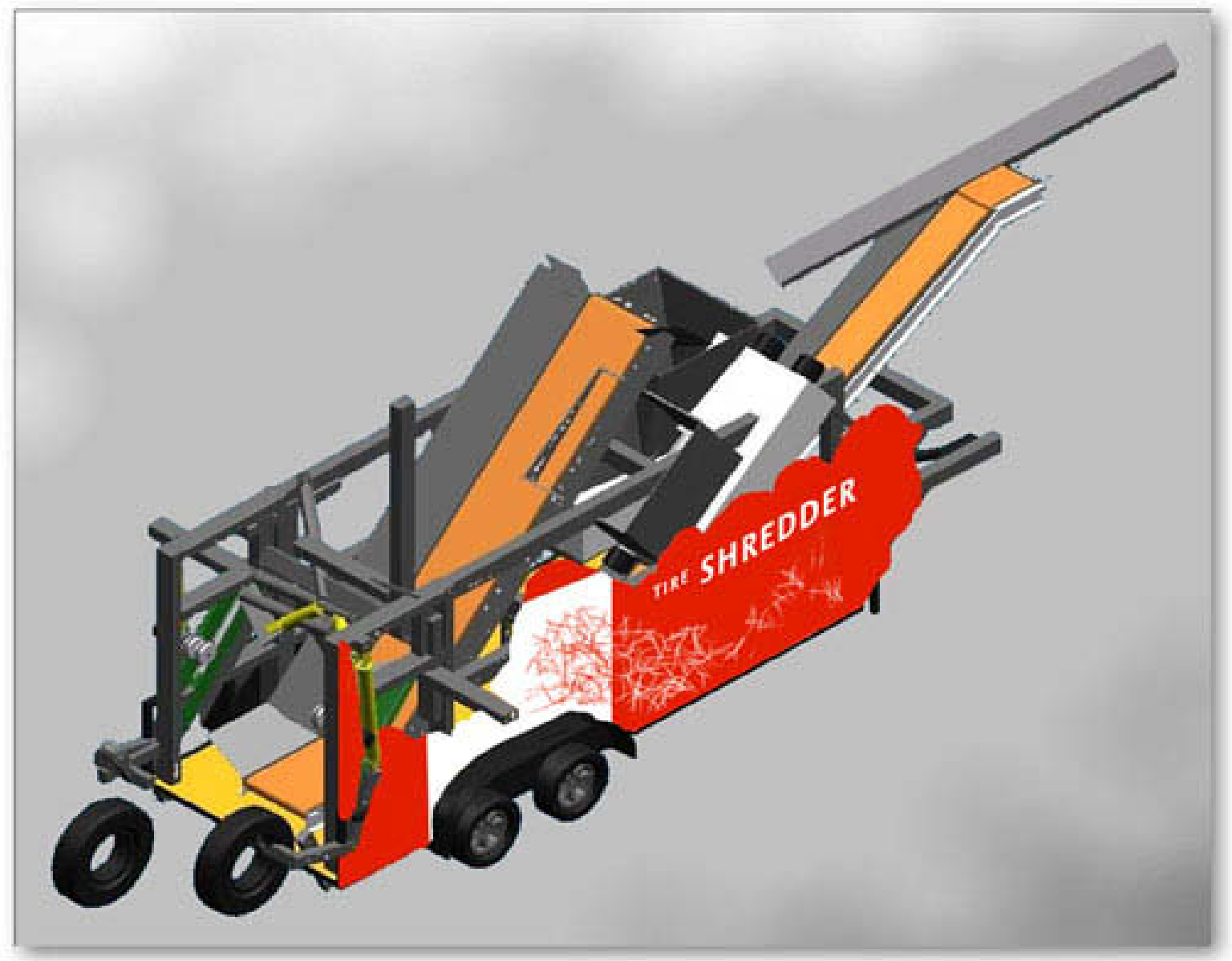

Figure 1: Schematic of Mobile Tire Shredding Unit 


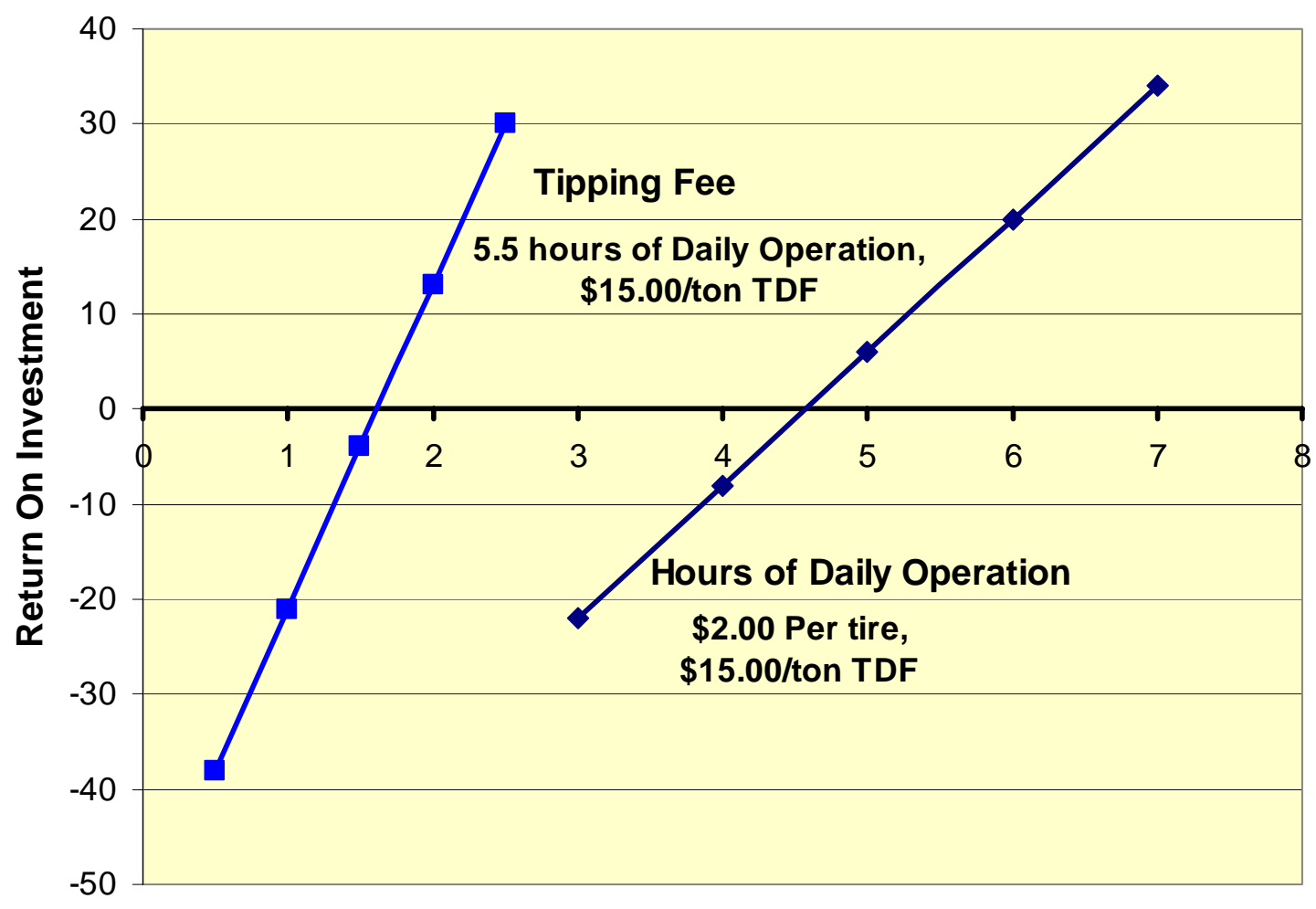

Figure 2: General Economic Analysis of the Mobile Shredding Unit: Return on Investment versus Tipping Fee and Hours of Daily Operation (assume \$500,000 purchase price and \$15/ton TDF) 


\title{
Attachment A
}

Public Law 99-502, the Federal Technology Transfer Act of 1986, as amended.

\author{
COOPERATIVE RESEARCH AND DEVELOPMENT \\ AGREEMENT (hereinafter "CRADA") No. 01-N044
}

BETWEEN

\begin{abstract}
NATIONAL ENERGY TECHNOLOGY LABORATORY (NETL)
U.S. DEPARTMENT OF ENERGY
\end{abstract}

\begin{abstract}
AND
Tiger Equipment Company (“Tiger Equipment or “Tiger”)

Mary Ellen Corp. (“Mary Ellen”)

American Bituminous Power Partners, L.P. (“American Bituminous”)

(these three hereinafter collectively referred as the "Participants")

all four being hereinafter collectively referred to as the "Parties"
\end{abstract}

The Parties agree to enter into this CRADA as authorized by law and in accordance with the following terms and conditions:

\section{ARTICLE I. DEFINITIONS}

A. "Government" means the United States of America and agencies thereof including the Department of Energy's National Energy Technology Laboratory (NETL).

B. "DOE" means the Department of Energy, an agency of the United States of America.

C. "NETL" is a Government-owned and operated facility engaged in the conduct of energy research and development.

D. "Laboratory Director" means the Director of the National Energy Technology Laboratory, acting in accordance with and under the general and enumerated authority of P.L. 99-502, as amended.

E. "Cooperative Research and Development Agreement" (CRADA) means an agreement as defined in and which conforms to the requirements of P.L. 99-502, the Federal Technology Transfer Act of 1986," as amended.

F. "Generated Information" means information produced in the performance of this CRADA. 
G. "Proprietary Information" means information which is developed at private expense outside of this CRADA, and embodies (i) trade secrets or (ii) commercial or financial information which is privileged or confidential under the Freedom of Information Act (5 U.S.C. § 552(b)(4)), and is marked as Proprietary Information.

H. "Protected CRADA Information" means Generated Information which is marked as being Protected CRADA Information by a Party to this CRADA, and which would have been Proprietary Information had it been obtained from a non-federal entity.

I. "Unlimited Rights" means the right to use, disclose, reproduce, prepare derivative works distributed to the public, and perform publicly or display publicly in any manner or for any purpose, or to permit others to do so.

J. "Subject Invention" means any invention of the Parties conceived or first actually reduced to practice in the performance of work under this CRADA.

K. "Intellectual Property" means patent applications, patents, and other forms of comparable property rights protected by Federal law and its foreign counterparts.

\section{ARTICLE II. STATEMENT OF WORK}

Tire Development for Effective Transportation and Utilization of Used Tires

Goals: (1) Research and develop via Vision 21 Virtual Plant Concepts a computer base design and model of a low energy tire reduction system. This system allows for effective transportation of waste tires due to size reduction and subsequent increases in bulk density at the collection point. (2) To field test the tire rendering system based upon the virtual design and then transport, and utilize the rubber chips produced as a co-fired fuel in a circulating fluidized bed boiler within the State of West Virginia (3) Identify other higher value uses for the transportable chip product. (4) Finally, document that the system is economically viable in the U.S. and possibly other countries.

\section{Scope of Work:}

Background

The concept is for an energy efficient, highly automated tire reduction system that allows for effective transportation of waste tires. Rudimentary evaluation has indicated the potential or an economically viable process.

\section{Phase 1}

- Upon approval of the Tire Development CRADA, NETL, Tiger Equipment, and Mary Ellen Corporation will develop detailed technical specifications and the design for a mobile processing system consisting of a truck and trailer designed to carry the tire processing equipment and haul the processed tires.

- All mobile tire processing equipment will be formally specified and appropriate drawings generated using NETL resources.

- NETL and American Bituminous Power Partner work to develop air testing and ash sampling plan to cover test burns of tires to take place at the Grant Town FBC plant during July of 2001. 
- All parties will make input to a generic public relations package needed to support the applications for air and ash permit modifications to a power plant's operating permits to allow the use of tires as fuel.

- American Bituminous Power Partner and NETL will modify the generic PR package for use in the Grant Town/Fairmount, West Virginia area.

- NETL will search for and evaluate routing software designed to analyze travel routes between potential used tire pick-up sites.

- NETL personnel will meet with Manitowoc Public Power and obtain operating data, and permit information on the co-firing of tires at Manitowoc's Lakeside Power Station in Manitowoc, Wisconsin.

\section{Phase 2}

- NETL resources complete sampling of both air and ash streams at the Grant Town Power plant.

- When the material and equipment specifications for the tire processing system are finalized; NETL, Tiger Equipment and Mary Ellen will jointly develop the first economic model. Tiger will supply estimated cost for the completed tire processing unit, Mary Ellen will supply a estimate, giving the range of tipping fees or funds it will receive for each tire process and the amount per ton of tire chip American Bituminous Power Partners is willing to pay. NETL may supply input on materials, labor and routing costs. NETL will then pull all the information together and prepare final document.

- $\quad$ Tiger Equipment Company will take the lead in fabricating economically viable processing equipment trailer for sale to Mary Ellen Corporation ${ }^{1}$.

- Routing software selected in Phase I will be used to determine the most economic routes for application of the mobile processing system based on potential sites or customers identified by Mary Ellen Corporation.

- Mary Ellen negotiates contracts with tire pick-up sites.

- Mary Ellen Corporation will put in place the necessary trucking equipment.

- NETL will compile testing information from American Bituminous Power Partner and from Manitowoc. A generic model will be developed for changing air and ash permits so power plants can burn the processed tires as a supplemental fuel. Using the generic model, NETL will assist American Bituminous Power Partner's Grant Town FBC plant in preparation of air and ash permit modification applications.

- $\quad$ PR campaign for Grant Town/Fairmount area begins.

- American Bituminous Power Partner will submit air and ash permit modifications to the State of West Virginia.

- $\quad$ Any appropriate process patents and/or trademark applications will be made.

1 Mary Ellen Corporation will purchase and Tiger Equipment will manufacture and sell at least one tire processing units resulting from this Agreement. Tiger Equipment hereby grants Mary Ellen Corporation the option to purchase three additional tire-processing units. The first two processing units will be sold at cost, which includes the actual costs to Tiger Equipment of all labor, materials, and taxes but excludes any profit. Mary Ellen Corporation and Tiger Equipment must negotiate the sale/purchase of any additional units beyond these first two. Mary Ellen Corporation may use these four tire processing units for the collection and processing of tires exclusively in the State of West Virginia. Mary Ellen Corporation hereby grants Tiger Equipment a right of first refusal to repurchase these four machines of their then fair market value. 
- When the process equipment trailer and the trucking and power train components are completed and attendant costs can be finalized, the NETL economic model will be revisited and updated.

\section{Phase 3}

- Tiger Equipment Company will deliver the completed process trailer to NETL's Bruceton site's fuel laboratory.

- Likewise, Mary Ellen Corporation will deliver trucking and/or power train components to the Bruceton site.

- Components would be joined together and NETL personnel from the Separation and Gasification Engineering Division will shakedown the equipment and work with the other Parties to fine-tune its operation.

- Size of the final tire chips and achievement of smooth, reliable, automated operation will be the goal of the shakedown team.

- $\quad$ Mary Ellen personnel will receive final training on the use of the routing software.

\section{Phase 4}

- Mary Ellen Corporation will embark on 9 months of field-testing and demonstration of the tire reduction and transport system with the chip product being used primarily as a supplemental FBC boiler fuel.

- American Bituminous Power Partners will purchase tire-derived fuel from Mary Ellen for the 18 month demonstration period at a mutually agreeable price to be determine by those two parties.

- Upon Mary Ellen's request, all parties will aid Mary Ellen in pursuing another tire processing opportunity in West Virginia during the field test period.

- Additional demonstrations (i.e. in the Wabash, Indiana area) with another tire collection operator may be pursued.

- During this period NETL and Tiger Equipment Company will provide maintenance support and technical assistance.

- Tiger Equipment will take the lead in identifying, at a minimum, 2 conferences where papers and presentations should be given. NETL, Mary Ellen, and American Bituminous Power Partner may pursue additional opportunities to present papers.

- Tiger will lead in preparation of the 2 draft papers or presentations. NETL to assist.

NETL will compile operation information and economic data for a final economic analysis and report.

\section{Phase 5 CRADA EVALUATION}

To aid NETL in evaluating its CRADA program, the Participants will provide NETL with a short narrative at the end of the CRADA addressing the following:

- $\quad$ Were your CRADA expectations met, not met, or exceeded?

- $\quad$ Estimate the cost savings to future projects due to the CRADA?

- $\quad$ Did the CRADA result in any product or knowledge which can be applied to future company programs without NETL involvement?

- $\quad$ Would you enter into another CRADA with the NETL? 
- $\quad$ What would you change about the CRADA development or CRADA implementation process?

- $\quad$ What is the largest potential impact this CRADA may have on your company (e.g., an increase in productivity, sales, new jobs created, new products, etc.)?

\section{ARTICLE III. TERM AND CONTRIBUTIONS OF THE PARTIES}

A. The terms of the CRADA, unless otherwise specified, shall remain in effect for three years commencing on the date the Laboratory Director signs this agreement.

B. The estimated value of the Participants' contribution is $\$ 416,868$.

Mary Ellen Corporation

American Bituminous Power Partners, L.P.

Tiger Equipment Company
In-Kind: $\$ 197,679.00$

In-Kind: $\$ 60,000.00$

In-Kind: \$159,189.00

The estimated value of the Government's contribution is $\$ 235,000.00$, subject to available funding.

D. The Parties shall have no obligation to continue or complete performance of the work at an amount in excess of the estimated contribution in paragraph B above, including any subsequent amendment.

E. Each Party agrees to provide thirty (30) days advance notice to the other Party if the actual amount to complete performance will exceed the estimated contribution.

\section{ARTICLE IV. PROPERTY}

All tangible personal property produced or acquired under this CRADA, shall become the property of the Participants or the Government depending on whose funds were used to obtain it. Such property is listed in Attachment A. Personal property shall be disposed of as directed by the owner at the owner's expense. All jointly funded property shall be owned by the Government.

Failure of the Participants to remove its property from federal property will establish a presumption of abandonment under federal property regulations.

To the extent that no Government-funded property is incorporated into the units, Mary Ellen Corporation shall have the option to purchase up to four tire-processing units from Tiger Equipment Company.

\section{ARTICLE V. DISCLAIMER}

THE GOVERNMENT AND THE PARTICIPANTS MAKE NO EXPRESS OR IMPLIED WARRANTY AS TO THE CONDITIONS OF THE RESEARCH OR ANY INTELLECTUAL PROPERTY, GENERATED INFORMATION OR PRODUCT MADE, OR DEVELOPED UNDER THIS CRADA, OR THE OWNERSHIP, MERCHANTABILITY, OR FITNESS FOR A PARTICULAR PURPOSE OF THE RESEARCH OR RESULTING PRODUCT. NEITHER THE GOVERNMENT NOR THE PARTICIPANTS SHALL BE LIABLE FOR LOST 
PROFITS, LOST SAVINGS, SPECIAL, CONSEQUENTIAL, INCIDENTAL OR OTHER INDIRECT DAMAGES ATTRIBUTED TO SUCH RESEARCH OR RESULTING PRODUCT, INTELLECTUAL PROPERTY, GENERATED INFORMATION, OR PRODUCT MADE OR DEVELOPED UNDER THIS CRADA.

\section{ARTICLE VI. PRODUCT LIABILITY}

Participants indemnify the Government for all damages, costs, and expenses, including attorney's fees, arising from personal injury or property damage occurring as a result of the making, using or selling of a product, process or service by or on behalf of the Participants, its assignees or licensees, which was derived from the work performed under this CRADA. In respect to this Article, the Government shall not be considered an assignee or licensee of the Participants.

\section{ARTICLE VII. RIGHTS IN GENERATED INFORMATION}

\section{A. Right to Use}

The Parties shall have unlimited rights in all Generated Information produced or provided under this CRADA, except for information which is disclosed in a Subject Invention disclosure being considered for patent protection, or marked as being copyrighted, Protected CRADA Information or Proprietary Information.

\section{B. Copyrighted Works}

For Generated Information, the Government retains for itself and others acting on its behalf, a royalty-free, non-transferable, non-exclusive, irrevocable worldwide copyright license to reproduce, prepare derivative works, distribute copies to the public, and perform publicly and display publicly, by or on behalf of the Government, all copyrighted works produced in the performance of this CRADA, subject to the restrictions this CRADA places on publication of Proprietary Information and Protected CRADA Information.

\section{ARTICLE VIII. OBLIGATIONS AS TO PROPRIETARY INFORMATION}

A. If Proprietary Information is orally disclosed, it shall be identified as such at the time of disclosure and confirmed in a written summary thereof within ten (10) days as being Proprietary Information of the provider.

B. Except as may otherwise be agreed to in writing by the provider, the Parties and the employees of the Parties, agree to use Proprietary Information only in the performance of this CRADA and to not further disclose such information to others, except to Government employees who are subject to the statutory provisions against disclosure of confidential information set forth in the Trade Secrets Act (18 USC 1905), or persons who have signed confidentiality agreements.

C. The Parties will mark Proprietary Information with the following legend: "PROPRIETARY INFORMATION - NOT AVAILABLE FOR DISSEMINATION." 
D. All Proprietary Information shall be returned to the provider thereof at the conclusion of this CRADA at the provider's expense or otherwise be disposed of by mutual agreement of the Parties.

E. All Proprietary Information shall be protected, unless and until such Proprietary Information shall become publicly known without the fault of the recipient, shall come into recipient's possession without breach of any of the obligations set forth herein by the recipient, or shall be independently developed by recipient's employees who did not have access to Proprietary Information, is intentionally released by the disclosing Party to a third party without restriction, or is released for disclosure with the written consent of the disclosing Party.

F. Attachment B contains a listing of the Proprietary Information which the Participants have identified at the time of signing the CRADA as necessary to provide to NETL in order to perform the work identified under this CRADA. Introduction of any additional Proprietary Information shall be by mutual agreement of the Parties.

\section{ARTICLE IX. OBLIGATIONS AS TO PROTECTED CRADA INFORMATION}

A. Each Party may mark as Protected CRADA Information, as defined in Article I, any Generated Information produced by its employees, and with the agreement of the other Party, mark any Generated Information produced by the other Party's employees.

B. The Parties will mark the cover of any document containing Protected CRADA Information with the following legend:

"PROTECTED CRADA INFORMATION

THIS DOCUMENT CONTAINS PROTECTED CRADA INFORMATION WHICH WAS PRODUCED ON __ [DATE] UNDER CRADA NO.01N044 AND IS NOT TO BE FURTHER DISCLOSED FOR A PERIOD OF 5 FROM THE DATE IT WAS PRODUCED EXCEPT AS EXPRESSLY PROVIDED FOR IN THE CRADA."

In addition, the Parties will mark each page of the document with the following legend: "PROTECTED CRADA INFORMATION."

C. For a period of five years (5) from the date Protected CRADA Information was produced, the Parties agree not to further disclose such Information except:

(1) as necessary to perform this CRADA;

(2) to be provided to other DOE facilities with the same protection in place,

(3) or as otherwise mutually agreed to by the Parties in advance. 
D. The obligations in paragraph $\mathrm{C}$ above shall end sooner for any Protected CRADA Information which becomes publicly known without fault of any Party, comes into a Party's possession without breach by that Party of the obligations of paragraph C above, or is independently developed by someone who did not have access to the Protected CRADA Information.

\section{ARTICLE X. EXPORT CONTROL}

THE PARTIES UNDERSTAND THAT MATERIALS OR INFORMATION RESULTING FROM THE PERFORMANCE OF THIS CRADA MAY BE SUBJECT TO EXPORT CONTROL LAWS AND THAT EACH PARTY IS RESPONSIBLE FOR ITS OWN COMPLIANCE WITH SUCH LAWS.

\section{ARTICLE XI. REPORTS AND ABSTRACTS}

A. The Participants will provide a nonproprietary abstract at the time the CRADA is submitted to the Laboratory Director for approval. Further abstracts may be required, for example, where a substantial change in scope or dollars occurs.

B. The Parties agree to produce the following reports:

(1) a final report, and

(2) other topical/periodic reports where the nature of the research and magnitude or dollars justify or as negotiated in Article II.

C. Any reports properly marked with a restrictive legend identifying the agreed-to period of withholding from public disclosure shall be used by the DOE for Department use only and shall be asserted to be exempt from the Freedom of Information Act as set forth at 5 U.S.C. 552.

\section{ARTICLE XII. PRE-PUBLICATION APPROVAL}

The Parties agree to secure pre-publication approval of any information to be published as a result of this CRADA other than that contained in the public abstract called for in Article XI. Such approval shall not be unreasonably withheld or denied. Failure to receive written response within thirty (30) calendar days from the date the document is received for review shall be considered by the requesting Party as pre-publication approval.

\section{ARTICLE XIII. REPORTING SUBJECT INVENTIONS}

A. The Parties agree to disclose to each other through the Administrative Contact listed in Article XXVII every Subject Invention that may be patentable or otherwise protectable under the Patent Act within two (2) months, or such longer period as is reasonably required, after the inventor first discloses the invention in writing to the person(s) responsible for patent matters of the disclosing Party.

B. Disclosure shall be in such detail as to be capable of enabling one skilled in the art to make and use the invention under 35 U.S.C. 112. The disclosure shall also identify any statutory bar that may exist and there shall be a continuing obligation on 
the Parties to further disclose any statutory bar that occurs for an invention disclosed but for which a patent application has not been filed. All invention disclosures shall be marked and treated as confidential under 35 U.S.C. 205.

C. The Parties agree to require, by written agreement, that their employees disclose each Subject Invention made under this CRADA promptly in writing to personnel responsible for patent matters. Further, the Parties agree that they will require their employees to execute or have executed and promptly deliver all instruments necessary for the filing and obtaining of patent protection on any Subject Invention.

\section{ARTICLE XIV. RIGHTS TO SUBJECT INVENTIONS}

A. Each Party shall have the first option to retain title to any Subject Invention solely made by its employees during the work under this CRADA. For joint Subject Inventions made by the DOE and the Participants, the Participants shall have the option of electing to retain title to its undivided rights and, if this option is elected, title to such Subject Inventions shall be jointly owned by the DOE and the Participants.

B. The Participants acknowledge that the DOE may obtain title to each Subject Invention for which a patent application is not filed, a patent application is not prosecuted to issuance, or for which any issued patent is not maintained by the Participants.

C. If the Participants elect to retain title to their own Subject Inventions, or if Tiger Equipment Company chooses an exclusive license to a NETL employee Subject Invention as provided below, the Government shall retain a nonexclusive, nontransferable, irrevocable, paid-up license to practice, or to have practiced, the invention by or on behalf of the United States throughout the world.

D. Tiger Equipment Company shall have the option to choose an exclusive license for equipment modifications made to tire shredding technology for any patents or patent applications made in whole or in part by employees of DOE/NETL under this CRADA. This option shall only be available to the Participants for a period of twelve months after the DOE reports the invention to the Participants or such longer time as may be approved by DOE. The Parties agree to negotiate in good faith to enter a separate mutually agreeable license agreement, including reasonable compensation, commercialization milestones, a U.S. Competitiveness Clause, March-in Provisions and other reasonable terms and conditions. If such license agreement is not completed within one year of initiation of good faith negotiations, the Government reserves the right to grant licenses to others in any and all possible applications.

\section{ARTICLE XV. FILING PATENT APPLICATIONS}

A. If the Participants elect to take title in any Subject Invention under Article XIV above, the Participants shall have the first opportunity to file U.S. and foreign patent applications; but if the Participants do not file such applications within twelve months after disclosure or 60 days prior to any statutory bar to patentability, whichever is earlier, then the Government may file patent applications and the Participants shall convey title in such Subject Inventions to the Government. 
B. If the Participants do not desire to file a patent application in any country in which it has the right to file for any Subject Invention, it shall notify DOE Administrative Contact listed in Article XXVII in writing of such negative intent within twelve (12) months after the initial disclosure of such invention but not later than 60 days prior to the time when any statutory bar might foreclose filing of a U.S. patent application.

\section{ARTICLE XVI. COST OF INTELLECTUAL PROPERTY PROTECTION}

Each Party shall be responsible for payment of all costs relating to copyright filing, U.S. and foreign patent application filing and prosecution, and all costs relating to maintenance fees for U.S. and foreign patents hereunder which are owned by that Party.

\section{ARTICLE XVII. REPORTS OF INVENTION USE}

The Participants agree to submit, upon request of DOE, a non-proprietary written report no more frequently than annually on its efforts to obtain commercial utilization of any Subject Invention to which the Participants holds title.

\section{ARTICLE XVIII. DOE MARCH-IN RIGHTS}

For Subject Inventions made solely by the Participants and for assignments and exclusive licenses by the Government to the Participants in Subject Inventions made in whole or in part by the Government, the DOE shall retain the right to require the Participants to grant a responsible applicant a nonexclusive, partially exclusive, or exclusive license to use the invention in any field of use, on terms that are reasonable under the circumstances, or if the Participants fail to grant such a license, to grant the license itself. DOE may exercise this right only in exceptional circumstances and only if DOE determines that (1) the action is necessary to meet health or safety needs that are not reasonably satisfied by the Participants; (2) the action is necessary to meet the requirements for public use specified by Federal regulations and such requirements are not reasonably satisfied by the Participants; or (3) the Participants have failed to comply with the provisions of Article XIX of this CRADA.

\section{ARTICLE XIX. U.S. COMPETITIVENESS}

The Parties agree that a purpose of this CRADA is to provide substantial benefit to the U.S. economy.

In exchange for the Benefits received under this CRADA, the Parties therefore agree to the following:

A. Products embodying Intellectual Property developed under this CRADA shall be substantially manufactured in the United States. This requirement may be waived by the DOE upon a showing by the Participant that reasonable but unsuccessful efforts have been made or that, under the circumstances, U.S. manufacture is not economically feasible. In order for the DOE to agree to foreign manufacture, the Participant must demonstrate that it has a plan for and commitment to providing appropriate alternate benefit to the U.S. economy, and 
B. Processes, services, and improvements thereof which are covered by Intellectual Property developed under this CRADA shall be incorporated into the Participants' manufacturing facilities in the United States either prior to or simultaneously with implementation outside the United States. Such processes, services, and improvements, when implemented outside the U.S. shall not result in reduction of the use of the same processes, services, or improvements in the United States.

\section{ARTICLE XX. ASSIGNMENT OF PERSONNEL}

A. It is contemplated that each Party may assign personnel to the other Party's facility to participate in or observe the research to be performed under this CRADA. Such personnel shall not during the period of such assignments be considered employees of the host Party for any purposes, including but not limited to any requirements to provide workers' compensation, liability insurance coverage, payment of salary or other benefits, or withholding of taxes.

B. Notwithstanding the foregoing, the host Party shall have the right to exercise routine administrative and technical oversight of the occupational activities of such personnel during the assignment period and shall have the right to approve the assignment of personnel or request their removal. The assigning Party's employees and agents shall observe the working hours, security and safety rules, and holiday schedule of the host Party while working on the host Party's premises.

C. Unless otherwise agreed to by the Parties, the assigning Party shall bear any and all costs and expenses with regard to its personnel assigned to the host Party's facilities under this CRADA. The host Party shall bear facility costs of such assignments.

\section{ARTICLE XXI. FORCE MAJEURE}

No failure or omission by the Participants or the Government in the performance of any obligation under this CRADA shall be deemed a breach of this CRADA or create any liability if the same shall arise from any cause or causes beyond the control of the Government or Participants as the case may be, including but not limited to the following: acts of God; acts or omissions of any government or agency thereof; compliance with requests, recommendations, rules, regulations, or orders of any governmental authority or any office, department, agency, or instrumentality thereof; fire; storm; flood; earthquake; accident; acts of the public enemy; war; rebellion; insurrection; riot; sabotage; invasion; quarantine; restriction; transportation embargoes; or failures or delays in transportation.

\section{ARTICLE XXII. ASSIGNMENT}

Any right acquired or assumed by the Participants pursuant to this CRADA is personal to it and may not be assigned or licensed without the prior written approval of the DOE, provided, however, that American Bituminous Power Partners, L.P. may assign this CRADA to its lender(s) pursuant to the Reimbursement and Loan Agreement dated January 1, 1990, as amended. Assignment of the CRADA does not relieve American Bituminous Power Partners of any liability incurred prior to the date of assignment. 


\section{ARTICLE XXIII. TERMINATION}

Participation by NETL in this CRADA is subject to the availability of appropriated funds. This CRADA may be terminated by any of the Parties upon 30 days written notice to the other. In the event of termination by any of the Parties, each shall be responsible for its share of the costs incurred through the effective date of termination as well as its share of the costs incurred after the effective date of termination and which are related to the termination. Any confidentiality obligations of the CRADA shall survive any termination of this CRADA except under the conditions provided for in Article IX.D. The non-terminating parties may agree to re-negotiate the CRADA in order to continue the project.

\section{ARTICLE XXIV. RECORDS AND ACCOUNTING FOR GOVERNMENT PROPERTY}

The Participants shall maintain records of receipts, expenditures and the disposition of all Government property in its custody related to the CRADA. Such records shall be subject to Government inspection.

\section{ARTICLE XXV. PUBLICITY/USE OF NAME ENDORSEMENT}

Neither of the Parties shall use the name of the other on any product, process, or service which is directly or indirectly related to either this CRADA or any patent, license or assignment which implements this CRADA without the prior approval of the other; nor shall any of the Parties represent that the other, by entering into this CRADA, directly or indirectly endorses any product, process or service provided, or to be provided, arising from the work done under this CRADA, by the Participants or their successors, assignees, or licensees.

\section{ARTICLE XXVI. DISPUTES}

The Parties will attempt to resolve any differences between them that may arise during the course of this CRADA. In the event that a dispute cannot be resolved between the Parties, the matter will be referred to the DOE's Board of Contract Appeals. The Board has established an Alternate Disputes Resolution (ADR) procedure which will be the first approach used in an attempt to resolve the dispute. Upon failure of the ADR process, the matter will be adjudicated by the Board using its regular contracts disputes procedure. In any event, this disputes process will not prevent either Party from terminating this CRADA in whole or in part under Article XXIII of this CRADA.

The construction, validity, performance, and effect of this agreement for all purposes shall be governed by the laws applicable to the Government of the United States.

\section{ARTICLE XXVII. NOTICES}

A. Any communications required by this CRADA shall be deemed made if mailed by postage prepaid first class U.S. Mail addressed to the Party to receive the communication as of the day of receipt of such communication by the addressee or on the date given if by verified facsimile. Address changes shall be given in 
accordance with this Article and shall be effective thereafter. All such communications, to be considered effective, shall include this CRADA Number.

B. The points of contact for the Parties are as follows:

NETL

Technical Contact:

Donald L. Bonk

MS D04

U.S. Department of Energy

3610 Collins Ferry Road

P.O. Box 880

Morgantown, WV 26507-0880

Phone: 304-285-4889

Fax: 304-285-4469

E-mail: Donald.Bonk@netl.doe.gov
Administrative Contact:

R. Diane Newlon

MS E01

U.S. Department of Energy

3610 Collins Ferry Road

P.O. Box 880

Morgantown, WV 26507-0880

Phone: 304-285-4086

Fax: 304-285-4403

Email: Roberta.Newlon@netl.doe.gov

Participants

Technical Contacts:

Mary Ellen Corporation

John (Jack) S. Depue

Route 3, Box 98

Bridgeport, WV 26330

Ph: 304-842-5924

Fax: 304-842-0190

PePaw1935@aol.com

Tiger Equipment Company

Joseph S. Fazio

13211 Griffin Run

Carmel, IN 46033

Ph: 888-965-3900

Fax: 317-843-9166

jfazio@acninc.net

IPP FBC Power Plant

American Bituminous

Power Partners, L.P.

Herbert Thompson

P.O. Box 159

Grant Town, WV 26574

Ph: 304-278-7449

Fax: 304-278-7437

hthompson@edisonmission.com 


\section{ARTICLE XXVIII. ENTIRE CRADA AND MODIFICATIONS}

A. It is expressly understood and agreed that this CRADA with its Attachments A and $\underline{B}$ contains the entire agreement between the Parties and that any other representations or agreements relating hereto have been merged into this document and are thus superseded in totality by this CRADA.

B. Any agreement to change any terms or conditions of this CRADA or the Attachments shall be valid only if the change is made in writing, executed by the Participants and the Laboratory Director.

FOR PARTICIPANTS:

FOR DOE:

BY

Mary Ellen DePue

BY

Mary Ellen Corp.

Rita A. Bajura

Director, NETL

DATE

DATE

BY

DATE

Jane Fazio, Secretary/Treasurer

Tiger Equipment Company

BY

DATE

Herbert Thompson

American Bituminous Power Partners, L.P. 


\section{ATTACHMENT A \\ PROPERTY TO BE USED IN CRADA NO. 01-F044}

\section{| Tiger Equipment Company}

Fabrication equipment or hand tools

Components of existing Tiger Equipment Company machines used to build mobilized trailer CD ROMS and diskettes

\section{Mary Ellen Corp.}

1 Tri-Axel or Tandem Dump Truck

\section{American Bituminous Power Partners, L.P.}

Circulating Fluidized Bed Boiler Facility at Grant Town, West Virginia

\section{ATTACHMENT B \\ PROPRIETARY INFORMATION}

\section{Tiger Equipment Company}

Concepts and ideas developed by Tiger Equipment Co. employees

Cam Roller System for Tire Slitter Machines

Financial and/or Materials Cost Information

Business Plan

Conceptual Sketches or Drawings

Computerized Drawings and Blueprints 


\title{
Tires as a Fuel
}

\author{
Public Meeting \\ Grant Town, WV \\ June 14, 2001
}

\section{It Is A Local Problem}

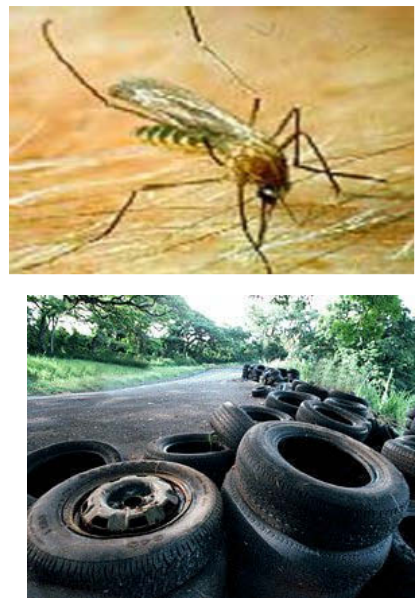

- This little devil has historically killed more people than all the wars

- Malaria

Encephalitis

Dengue Fever

Others

- AND his favorite home is a Scrap Tire 


\section{This is a Local Problem}

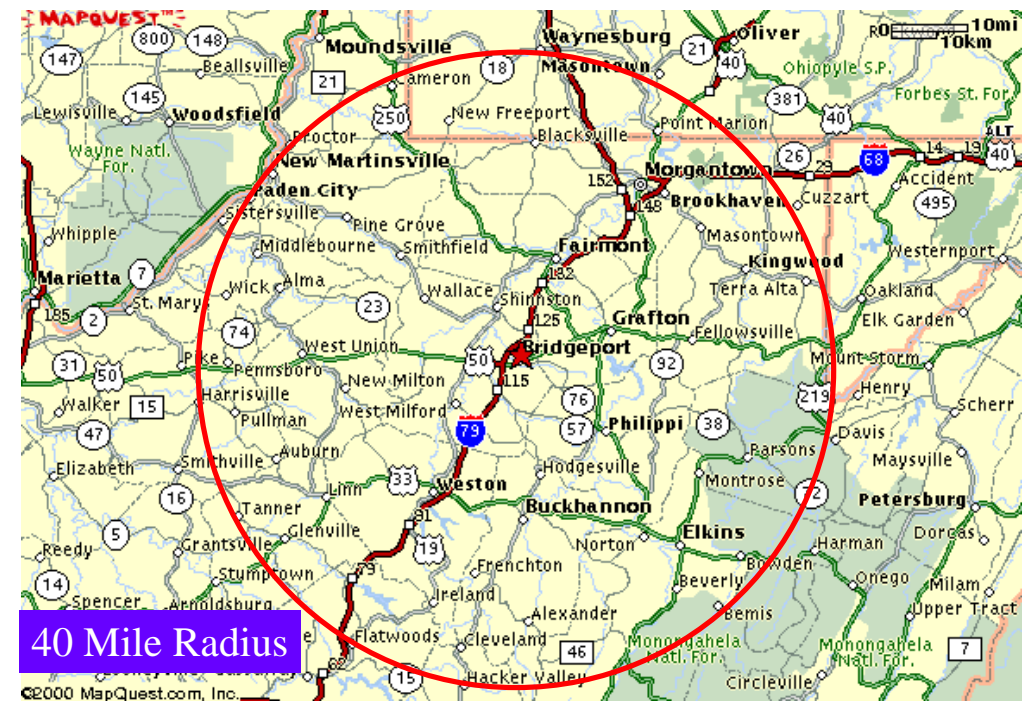

\section{Population in 40 miles of Bridgeport}

\section{According to 2000 US Census}

About 340,000 people in that region

Rule of thumb - 1 tire per person

At $20 \mathrm{lbs} / \mathrm{tire}$, this is 3,400 tons/year of waste tires generated in this area per year.

One Demonstration Unit would only handle half of this volume 


\section{Open Burning}

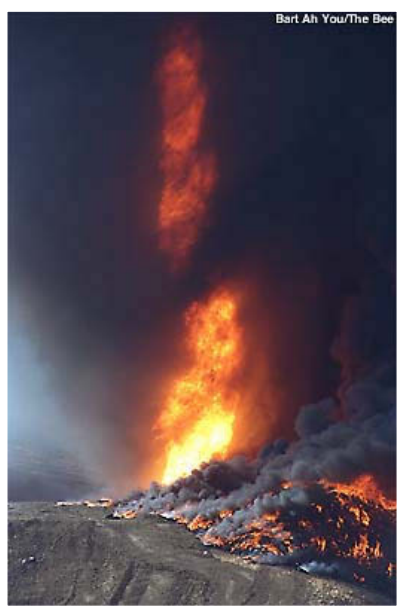

Opening Burning is not a proper combustion process it always lacks the proper amount of air and can have areas of low temperature ( Under 600F).

Opening burn is banned or restrict in all of the United States, because of all the environmental problems, both air and water pollution

Opening Burning is not what is proposed for Grant Town

\section{Open vs. Controlled Burning}

All 50 states have banned Open (outdoor) burning of tires except in very special circumstances

Combustion of tires as a fuel is encouraged by USEPA and several states $(\mathrm{OH}, \mathrm{WV}, \mathrm{IL}$, $\mathrm{MI})$ 


\section{Tire Burning - A Combustion \\ Primer}

- Opening Burning is not a proper combustion process it always lacks the proper amount of air and can have areas of low temperature (Under 600F)

- Three components of fire or good combustion

$$
\begin{aligned}
& \text { Fuel } \\
& \text { Heat } \\
& \text { Air (Oxygen) }
\end{aligned}
$$

The Burning in a Fluidized Bed is the application of proper combustion techniques.

Air is at least $20 \%$ greater than needed to burn the tire

Temperature is $\sim 1600 F$, this red hot through out the burning cycle

Shark chips are prepare fuel, finer in size than currently used.

\section{Market Driven Fuel}

1998, 72 facilities using TDF

Number is smaller than previous years

- Environmental Concerns not a reason for any of the closings or reduction in use

End use market has changed from 3" chip to 2" and smaller. Process for Grant Town will produce a 1" chip. 


\section{Basic Composition}

\begin{tabular}{|l|r|r|r|}
\hline & Coal & Tires (as receved) & Grant Town Fuel \\
\hline Moisture & \multicolumn{1}{|c|}{6} & $.62 \mathrm{wt} \%$ & 11.61 \\
\hline Ash & 9.34 & 4.78 & 34.49 \\
\hline Carbon & 65.43 & 83.87 & 41.38 \\
\hline Hydrogen & 4.88 & 7.09 & 3.34 \\
\hline Nitrogen & 1.15 & .24 & .94 \\
\hline Sulfur & 2.73 & 1.23 & 2.2 \\
\hline Oxygen & 10.76 & 2.17 & 6.05 \\
\hline
\end{tabular}

\section{Trace Metals}

\begin{tabular}{|l|l|l|l|}
\hline & Coal & Tires & Grant Town Fuel \\
\hline Zinc & .00027229 & $\begin{array}{l}1.52(\mathrm{wt} \% \text { as } \\
\text { received) }\end{array}$ & .0000512 \\
\hline Iron & 1.92 & .321 & \\
\hline Chromium & .00001375 & .0097 & .0000203 \\
\hline Fluoride & .00006094 & .0010 & \\
\hline Cadmium & .00000252 & .0006 & .0000450 \\
\hline Lead & .00003478 & .0065 & .0000124 \\
\hline
\end{tabular}




\section{Heating Value}

Coal - 12,450 BTU/lb

Tires - 15,500 BTU/lb

Grant Town - 7750 BTU/lb

\section{Not an Experimental Technology}

72 facilities in US burn tires. Some of these started before 1990 .

ADM alone has 9 FBC facilities in the MidWest that use tires as a fuel

Willow Island Station in Parkersburg, WV is presently burning tires with great success.

- Alliant energy has 3 Cyclone Plants in upper mid-west 


\section{Tire Burning FBC Facilities}

Wyandotte, MI

Kapalei, HI

Rumford, ME

Dublin, GA

\section{Holnam's TDF Locations}

Dundee, Michigan

Theodore, Alabama

Clarksville, Missouri Ada, Oklahoma

- Mason City, Iowa

Midlothian, Texas

Artesia, Mississippi

- Portland, Colorado

- Devil's Slide, Utah 


\section{Why Not Morgantown?}

Constrained by Space - No place to put tire fuel

Constrained by Technology - No equipment to feed fuel

- Constrained by Distance - Grant Town is closer to Bridgeport HQ of Trucking Co.

$\square$ None of these problems exist at Grant Town

\section{Environmental Advantages}

In General:

“TDF has long been recognized as a potential fuel. It compares favorably to coal. It has higher heating value, less moisture, more carbon, about as much sulfur as medium sulfur coal, but much less fuel-bound nitrogen.” --EPA 1997 report: “Air Emissions From Scrap Tire Combustion"

“The combination of long residence time and high temperatures make cement kilns an ideal environment for TDF. Emissions are not adversely affected compared to baseline fuels and often represent an improvement.” --EPA 1997 report 


\section{Environmental Advantages}

\section{In General:}

Scrap tires should be considered a resource rather than a waste material; and scrap tires have been combusted in an environmentally sound manner". -- Ohio Air Quality

Development Authority, 1991

"Emission tests at two cement kilns burning waste tires with coal fuel showed no appreciable difference in toxic air contaminant emissions when compared to burning coal fuel only." "The Board recommends that support be provided for use of tires as fuel in cement kilns.”

-- California Integrated Waste Management Board, 1992

\section{Environmental Advantages}

EPA Research Center kiln simulation test:-- (EPA 1997 report)

"It is concluded that, with the exception of zinc emissions, potential emissions from TDF are not expected to be very much different than from other conventional fossil fuels, as long as combustion occurs in a well-designed, well-operated and well-maintained combustion device. If unacceptable particulate loading occurs as a result of zinc emissions, an appropriate particulate control device would need to be installed*”.

* Experiences show that with high-efficiency PM control devices, such as a $\underline{b a q}$ filter, zinc emissions from TDF can be controlled to the same level as when solely using coal. 


\section{Midwest Regional Scrap Tire Conference - June 5-6, 2001}

\section{Tire Derived Fuel}

60 to $65 \%$ of all tire utilized are as fuel ASTM Standard In the works, Proposed Grant Town fuel would exceed specification Wood fired boiler (Stabilizing)

- Utility Boiler, The Alliant Energy Story

- TDF Testing at Prudue University, Confirms FBC is proper unit., not a stoker

Cement kilns, The Holnman Story

\section{Midwest Regional Scrap Tire Conference - June 5-6, 2001}

Civil Engineering Applications

- Specification by University of Maine

- Light Weight Fill Projects by Purdue University and INDOT

- Landfill Usage University of Illinois

- Use in Septic Fields, Better than rock support "good' microbes by South Carolina Dept of Health and environmental control 


\section{Midwest Regional Scrap Tire Conference - June 5-6, 2001}

Tire Reclaiming, US usage

700 million tons/year

1998, 70 million tons/year

NO USA Firms Involved due to environmental restriction, third world activity

USA uses SBR

Ground Rubber Markets

- Soil amendment by Pioneer-Randustiral

- Play grounds, Florida Tire Recycling

Testing and how to use

\section{Midwest Regional Scrap Tire Conference - June 5-6, 2001}

\section{State Programs}

- Illinois presented program

- Indiana presented program

- Kentucky did not present program

- Michigan did not present program

- Pennsylvania presented program

West Virginia did not show up

Wisconsin did not present program 


\section{Zinc Emissions are Small}

99.4\% of the $\mathrm{Zn}$ in the tires will be captured in the FBC bottom ash and the fly ash captured in the bag house (16th IFBC)

\section{Testing Protocol}

Continuous Emissions Monitoring for standard air emissions

Remote sensors for air born emissions and solids

- Ash testing for composition including trace material 


\section{Communications and Timing}

Don't expect problems. However, the test period could be moved to September 15th

- Will set up a $24 \mathrm{hr}$ hotline to report potential problems during the test period

Will run test so it can be stopped within ?? Minutes/hours

\section{A Little Perspective}

1:4000 dying in an auto accident in your lifetime (US Department of Transportation)

1:100,000 dying in an industrial accident in your lifetime (all industries, coal mining is worse, OSHA)

1:80 million dying from power plant pollution (EPA statistics, same as winning Powerball Jackpot) 


\title{
Scrap Tire Disposition
}

\section{According to Scrap Tire Management} Council

\author{
$66 \%$ consumed
}

- $12 \%$ landfill

- $10-12 \%$ reuse

- 14-16\% unaccounted for

\section{Scrap Tire Usage}

\begin{tabular}{|l|l|l|}
\hline \multicolumn{2}{|l|}{ Estimated total Scrap Tire Market 1998} & 114 million tires \\
\hline Fuel Cement kilns & 38 million & \\
\hline Pulp/Paper mills & 20 & \\
\hline Dedicated tires to energy & 16 & \\
\hline Electric Utilities & 25 & \\
\hline$\quad$ Industrial boilers & 15 & \\
\hline Civil Engineering & & 20 million \\
\hline Products & & 23 million \\
\hline$\quad$ Ground Rubber & 15 million & \\
\hline Cut/Punched/Stamped & 8 & \\
\hline Miscellaneous/Agriculture & & 5.5 million \\
\hline Export & & 15 million \\
\hline Total & & 177.5 million \\
\hline
\end{tabular}




\title{
Reasoning with Fear?
}

\author{
Prepared for \\ Grant Town Public Meeting
}

August 2, 2001

\section{Disclaimer}

This presentation reviews all of the questions raised at the 2 public meetings held in Grant Town concerning a proposal to burn processed waste tires at the Grant Town power production facility. 


\section{FDR Had it Right}

$\square$ So, first of all, let me assert my firm belief that the only thing we have to fear is fear itself - nameless, unreasoning, unjustified terror, which paralyzes needed efforts to convert retreat into advance. - FDR, first Inaugural address, March 4, 1933

In summary, fear is the only issue in Grant Town

\section{Rodriguez Soot Sample - 7/14/01}

Mr. Rodriguez presented DOE with soot sample taken from patio of home. He demanded analysis.

- June 19 - Mr. Rodriguez calls DOE with suspision that material is from his new roof shingles 


\section{Rodriguez Soot Sample - 7/14/01}

continued

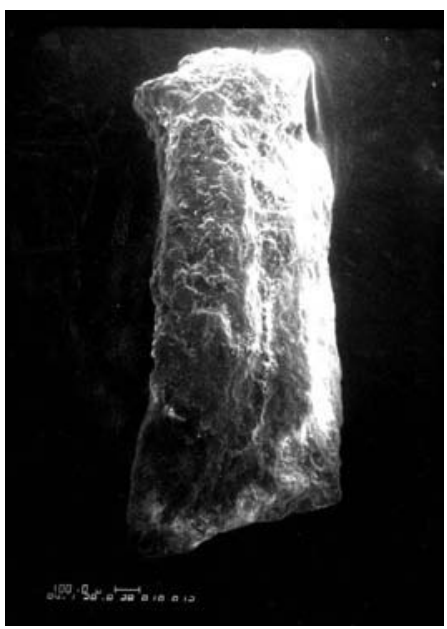

July - DOE analysis confirms that material is fly ash produced by a pulverized coal boiler

The Grant Town power plant cannot produce this type of ash. The Grant Town power plant is a fluidized bed combustion system. The ash produced is different than the sample given to DOE by Mr. Rodriguez

\section{Waste Tires is a Local Problem}

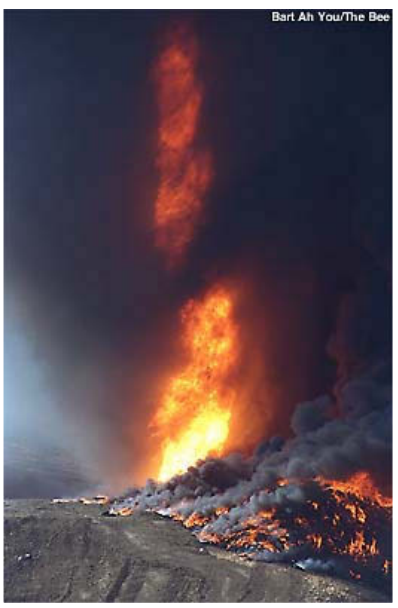

A fire inside a tire pile can happen anywhere, including Marion County. A burning tire pile is a very serious health hazard. 


\section{It Is A Local Problem}

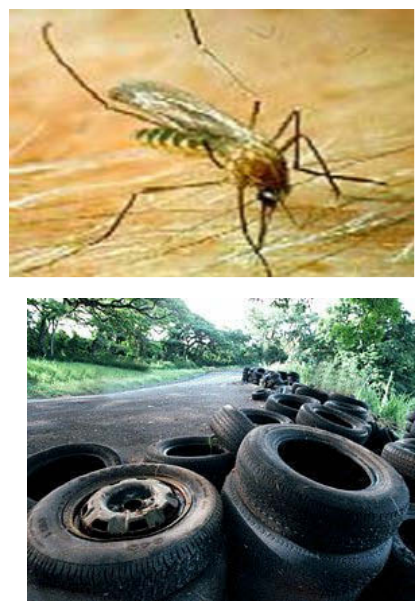

This little devil has historically killed more people than all the wars

\section{Malaria}

Encephalitis

Dengue Fever

Others

AND his favorite home is a Scrap Tire

\section{The Demonstration is Targeted at the Local Problem}

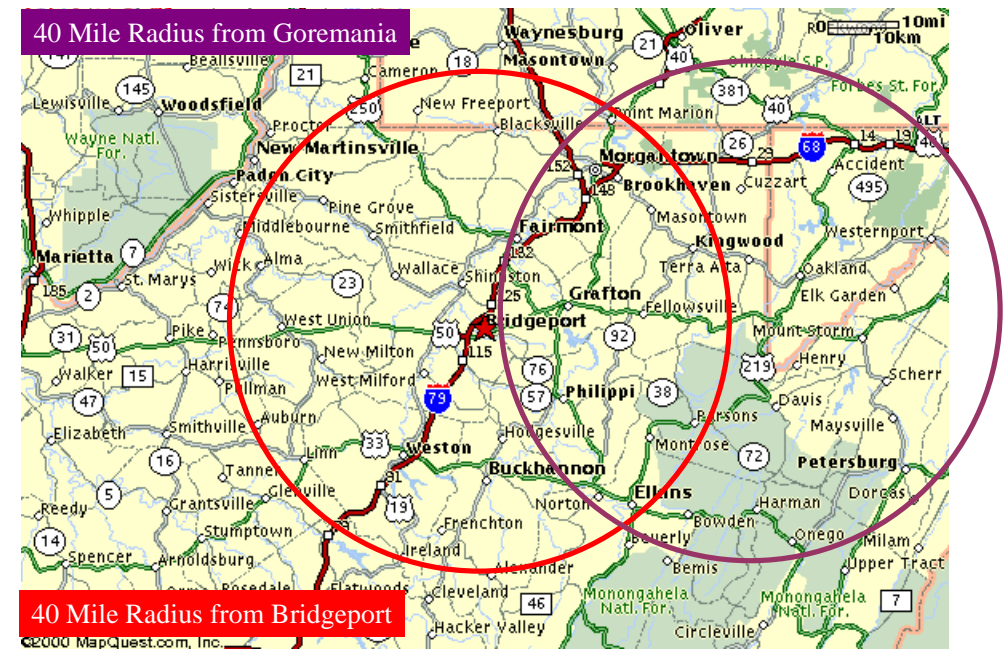




\title{
Population in 40 miles of Bridgeport
}

\author{
According to 2000 US Census
}

About 340,000 people in 40 mile region

Rule of thumb - 1 waste tire per person per year

- At $20 \mathrm{lbs} / \mathrm{tire}$, this is 3,400 tons/year of waste tires generated in this area per year.

One Demonstration Unit would only handle half of this volume

\section{A Tire Pile Fire is Open Burning}

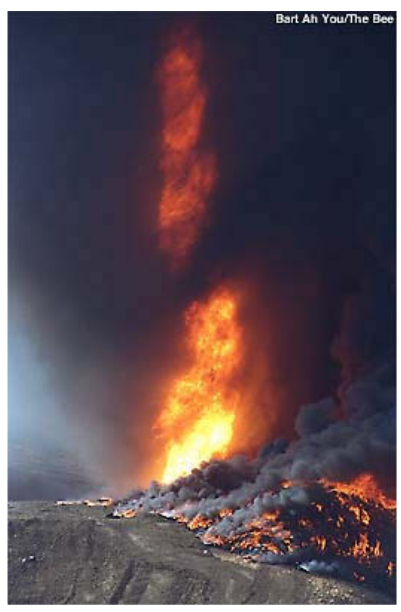

Opening Burning is not a proper

combustion process. It always lacks the proper amount of air and can have areas of low temperature ( Under 600F).

Opening burning is banned or restricted in all of the United States, because of all the environmental problems, both air and water pollution

Opening Burning is not what is proposed for Grant Town 


\section{Open vs. Controlled Co-firing}

All 50 states have banned Open (outdoor) burning of tires except in very special circumstances

Combustion of tires as a fuel is encouraged by USEPA and several states $(\mathrm{OH}, \mathrm{WV}, \mathrm{IL}$, MI)

Tire co-firing at the Grant Town plant will be a controlled process at a minimum of $1600 \mathrm{~F}$ in a combustion furnace

\section{Tire Co-firing - A Combustion}

\section{Primer}

- Opening Burning is not a proper combustion process it always lacks the proper amount of air and can have areas of low temperature (Under 600F)

- Three components of fire or good combustion

$$
\begin{aligned}
& \text { Fuel } \\
& \text { Heat } \\
& \text { Air (Oxygen) }
\end{aligned}
$$

The co-firing of tires in a Fluidized Bed is the application of proper combustion techniques.

Air is at least $20 \%$ greater than needed to burn the tire chips

Temperature is $\sim 1600 F$, this is red hot through out the burning cycle

Tire chips are prepared fuel, finer in size than currently used. 


\section{What about Vinyl Chloride in Tires?}

Modern tires do not contain vinyl chloride

- If some was in older tires, vinyl chloride is destroyed at the operating temperature of the Grant Town plant

Grant Town FBC operates at temperatures $>1500 \mathrm{~F}$ so vinyl chloride is not present in the stack gas and is not an issue

\section{How are the emissions from the tires going to effect us and our children?}

$\square$ Let us put this in perspective

1:80 million dying from power plant pollution (EPA statistics) (same as winning Powerball ${ }^{\mathrm{TM}}$ Jackpot)

1:4000 dying in an auto accident in your lifetime (US Department of Transportation) 1:100,000 dying in an industrial accident in your lifetime (all industries, coal mining is worse, OSHA) 


\section{Transportation Issues}

- Citizens complained about the large amount of truck traffic bringing in present fuel and limestone. Will burning tires add to that problem?

\section{Trucking Issues}

The burning of waste tires will not increase the number of trucks

- Tires contain twice as much energy per volume than waste coal

- Using tires as fuel as proposed will reduce the number of trucks by 1 for every 100 waste coal trucks needed now 


\section{Why Experiment in Grant Town?}

This is NOT an experimental technology 72 facilities in US burn tires. Some of these started before 1990.

ADM alone has 9 FBC facilities in the MidWest that use tires as a fuel

Willow Island Station in Parkersburg, WV is presently burning tires with success.

- Alliant energy has 3 Cyclone tire fueled Plants in upper mid-west

\section{Tire Burning FBC Facilities}

- Wyandotte, MI

Kapalei, HI

Rumford, ME

Dublin, GA

- Generally these units use a 2" chip. The DOE proposal will use a 1 " chip producing cleaner results. 


\section{What is Different about Grant Town Proposal?}

Standard for Tire Derived Fuel (TDF) is a 2" chip

American Society for Testing and Materials (ASTM) has drafted a specification for 2" TDF

Grant Town fuel would be a 1" TDF chip

- better material handling characteristics

- smaller size, better fluidization in combustor

- faster combustion processing

\section{What about Morgantown FBC?}

If fluidized bed is so wonderful, why not use the facility in downtown Morgantown? 


\section{Why Not Morgantown?}

Constrained by Space - No place to put tire fuel

Constrained by Technology - No equipment to feed/mix fuel

- Constrained by Distance - Grant Town is closer to Bridgeport HQ of small trucking operation

None of these equipment or transportation problems exist at Grant Town

\section{No Mosquito Problem Locally}

- Grant Town citizen believes that local waste tires are not a mosquito problem. 


\section{LaCrosse Encephalitis}

Health and Human Resources department of WV reports that LaCrosse encephalitis is a major problem particularly in southern WV and is spreading north through mosquitoes.

Encephalitis is inflammation of the brain tissue - causes headaches, fever, disorientation, convulsion, coma and death

\section{LaCrosse Encephalitis continued}

Odds of getting 1:38,000 in WV and getting worse

- Children are at greater risk

- LaCrosse encephalitis has been reported in Monongalia county West Virginia 


\section{LaCrosse Encephalitis continued}

- HHR of WV states that clean-up of waste tires (eliminating mosquito breading ground) is single most important step to stop spread of LaCrosse encephalitis

\section{West Nile Encephalitis}

- Charleston Gazette - April 19, 2001 - "State to Prepare for West Nile Virus"

Virus infections are moving south and west from Pennsylvania and Maryland

West Virginia Health Department has been given $\$ 150,000$ by US Center for Disease Control to create an action plant to stop spread of virus 


\section{Tires have a lot of Zinc in them. Is this a problem?}

- OSHA, NIOSH, ACGIH has placed limits on exposure to zinc oxide $(\mathrm{ZnO})$ of $5 \mathrm{mg} / \mathrm{m}^{3}$ for 8 hour time weighted average

- Under the conditions of the proposal, the amount of $\mathrm{ZnO}$ leaving the stack is .0716 $\mathrm{mg} / \mathrm{m}^{3}$ or 70 times below the most stringent limit

\section{Tires have a lot of Zinc in them.} Is this a problem? continued

- Above conditions assumes you are standing on the top of the discharge stack. Normal dispersion will reduce the $\mathrm{ZnO}$ to even lower levels 


\section{What about the October 1998 Tire Test}

Burn? Has DOE reviewed that report?

During the entire test period, the plant met or exceeded state emissions regulations

- There was no indication of increase dust emissions

- $\mathrm{SO}_{2}$ and $\mathrm{NO}_{\mathrm{x}}$ control was improved

What about the October 1998 Tire Test Burn? Has DOE reviewed that report? continued

Ash samples indicated Zinc concentrations well below levels where they wold effect human heath

- In summary, overall results indicate a positive effect on operations 


\section{The West Virginia Serria Club stated that Dioxins can be Formed}

\section{Dioxin}

Can only form in a specific temperature range (400-1200F) with high concentrations of water/steam and chlorine or other similar elements.

These conditions DO NOT EXIST in a fluidized bed unit

Fluidized Bed is designed to avoid dioxin production- it operates above $1500 \mathrm{~F}$

- Dioxin is not an issue with tire co-firing

\section{Why not burn only good WV coal?}

Tire co-firing is a benefit to the $\mathrm{WV}$ coal industry

Tire co-firing improves operations of coal burning plants helping coal be a cleaner and reliable fuel

Tire co-firing extends the life of mines and coal resources so there can be future generations of well paid miners 


\section{Ms. Wilson's Issues}

Why is the federal Government not showing commitment to the Kyoto "Global Warming" Treaty?

- There is no signed agreement by the US concerning "Global Warming." The US Senate rejected the treaty 98-0 in 2000 due to "major flaws" in the agreement.

\section{Ms. Wilson's Issues continued}

The Grant Town plant will poision my children just like the plant did in Bophal, India

None of the chemicals involved with the Bophal tragedy are used in the Grant Town plant. The event cannot happen in Grant Town. 


\section{Ms. Wilson's Issues continued}

What about the soot material from the October 1998 test?

The samples taken were too small for the state laboratory to give a definitive answer

- Regardless, the power plant monitors did not indicate any increase in emissions from the plant during the testing

- Informally, indications are that all sampled material was not from the power plant

\section{FDR Had it Right}

So, first of all, let me assert my firm belief that the only thing we have to fear is fear itself - nameless, unreasoning, unjustified terror, which paralyzes needed efforts to convert retreat into advance. - FDR, first Inaugural address, March 4, 1933

- In summary, fear is the only issue in Grant Town 


\section{Lessons Learned from Grant Town}

September 13, 2001 


\section{Federal and State Regulators}

- All permits should be in place before contacting anyone outside of CRADA group 


\section{Sierra Club}

- Tire Derived Fuel (TDF) is a national target

- Any and all means will be used

$\checkmark$ Dioxin

$\checkmark$ Request for Bonding against damage

$\checkmark$ Request for excessive testing (air and solid) 


\section{Local Luddites}

- Learn any history before any public announcments 


\section{Local Luddites}

- Public meetings are to inform only not to ask permission

All state and federal permits should be in place before meeting

- Target audience is large populace, not the small group of protesters

- Make protesters produce specific evidence and specific concerns 


\section{Local Luddites}

- Learn any history before any public announcments 


\section{Local and State Politics}

- Need to contact local government before going public and after plans are in place

sell local politicians on environmental benefits

- Need to contact state reps/senators before going public and after plans are in place

sell state politicians on environmental benefits and benefit to coal industry 


\section{Local Regulators}

- Local waste management board or other entities do NOT have any standing with this activity 


\title{
The 28th International Technical Conference on Coal Utilization \& Fuel Systems Program Abstract March 10-13, 2003
}

\section{Production of Tire Derived Fuel: Use of Mobile System as a Viable Economical Alternative}

Susan M. Maley

U.S. DOE

National Energy Technology Laboratory

3610 Collins Ferry Road PO Box 880

Morgantown, WV 26507-0880

Susan.maley@netl.doe.gov

P 304-285-1321

F 304-285-4403

Mr. Jack S. Depue

Mary Ellen Corporation

119 Maple Lake

Bridgeport, WV 26330

P 304-842-5924

F 304-842-0190

PePAW1935@aol.com
Donald L. Bonk

U.S. DOE

National Energy Technology Laboratory

3610 Collins Ferry Road PO Box 880

Morgantown, WV 26507-0880

Don.bonk@ netl.doe.gov

P 304-285-4889

F 304-285-4777

Mr. Richard L. Cook Sr.

JANRT

725 West Centennial Ave.

Muncie, IN 47303

P 765-282-3014

F 317-843-9166

tirestoenergy@hotmail.com

\begin{abstract}
Scrap tires represent a significant source of alternative high BTU fuel for a variety of combustion systems with the largest market being existing and permitted facilities that employ rotary kilns, fluidized beds, or traveling grate boilers. Most of these systems that use Tire Derived Fuel (TDF) are for the manufacture of cement and power. While TDF has been used on a fluctuating basis for many years, an unstable market surrounding tire recycling and production of TDF exists. One factor contributing the market instability is the energy intensive practices required to process whole tires in to 1 " 1 1" TDF chips, so that it can be readily used by those facilities capable of co-firing with coal, biomass, or waste products.

Traditionally, whole tires are picked-up from a retailer and transported to a processing facility followed by delivery to an end user. In situations where a large number of scrap tires exist, such as abandoned tire piles, equipment can be brought to the site for full or partial processing of the tires. While the second scenario works well for large tire piles, it is not an economical approach to managing the on going production of used/scrap tires produced on a daily basis throughout the country. For this scenario, it is recognized that an economical approach to producing TDF needs to be offered to those involved with supplying TDF fuel.

Using this scenario, the National Energy Technology Laboratory and it's small business partners JANRT and Mary Ellen Trucking are working together to design and operate a completely mobile unit that generates 1'x1" wire-in chips. The mobile unit comprises of a large dump truck and enclosed trailer that houses the automatic tire processing units. The mobile unit will be routed throughout a region processing tires at the retailer followed by delivery to the end user or temporary storage. The primary advantages of the mobile unit are 1) a single process / step to process and transport the 1"x1" TDF chips and 2) the ability to transport a much larger number of equivalent tires as processed TDF. The mobile unit is capable of processing two tires per minute and can accept tire sizes ranging from small car to light duty truck. With average chip size of 1 "x1", the presence of wire is not expected to present operational issues for the majority of suitable combustion facilities.

While this unit has clear advantages over a multi-transport, multi-stage processing approach, the economics are primarily driven by the tipping fees established for the state or region. At this early stage, the initial economics suggest that this system will be profitable using the current fees applied to new tire sales or used tire disposal. Following a demonstration of the system, the ability to operate profitably at a fraction of established tipping fees will be determined. If so, this mobile unit may serve as the primary choice for processers involved in the generation of TDF materials.
\end{abstract}




\section{Production of Tire Derived Fuel: Use of a Mobile System as a Viable Economic Alternative}

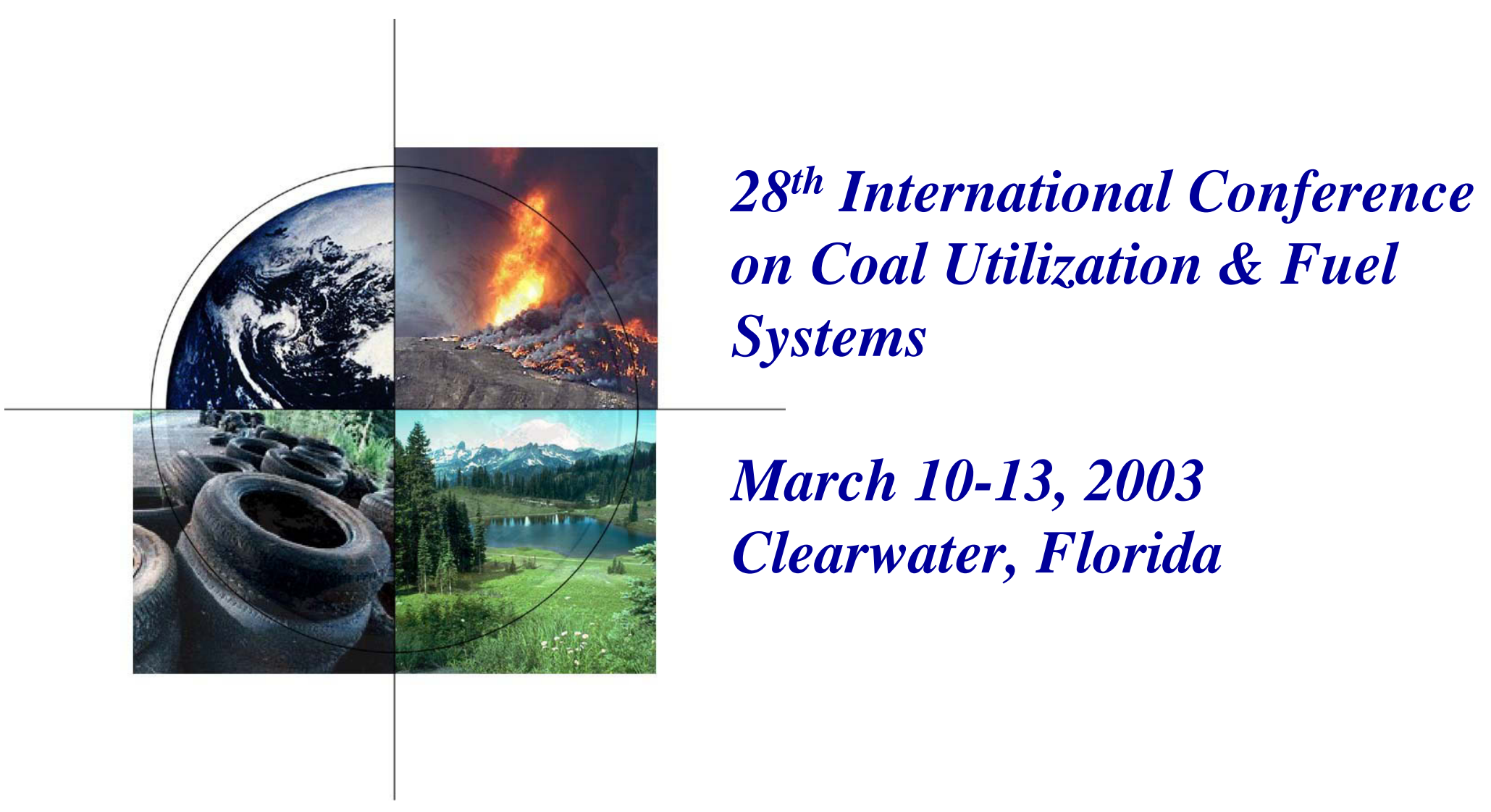

Don Bonk and Susan Maley

Office of Fossil Energy, National Energy Technology Laboratory

Richard Cook, JANRT Tire Recycling Equipment

Jack Depue, Mary Ellen Trucking Corporation 


\section{Outline}

- The problem with tires

- Solutions for reuse, recycle, or disposal

- Tire derived fuel

- Use of mobile equipment to process tires

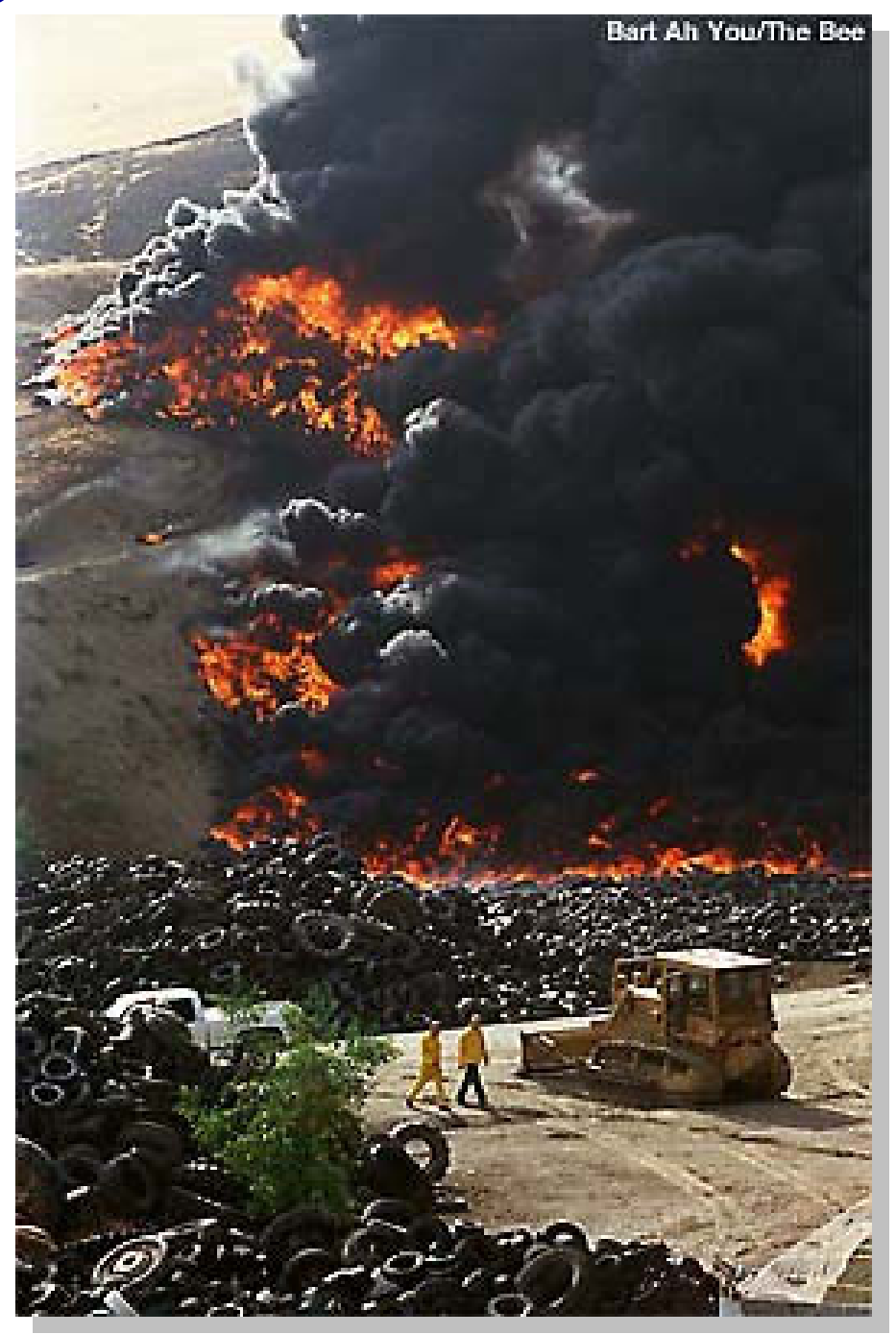

NETL 


\section{National / State / Regional / Local Problem Multi-faceted Environmental Issue}
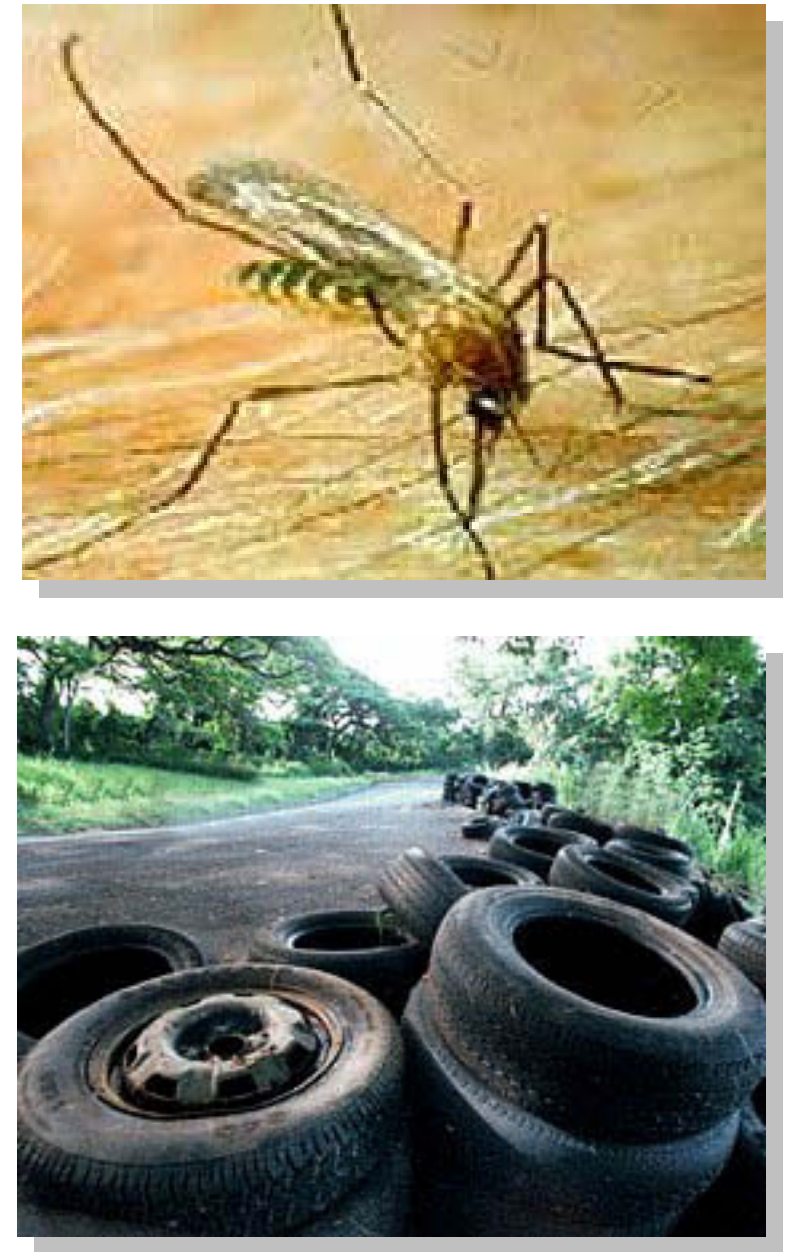

- Mosquitoes

- West Nile

- Malaria

- Encephalitis

- Dengue Fever

- Others

- Breed up to 4000 times faster

- Snakes and rats

- Aesthetics

- Tire pile fires

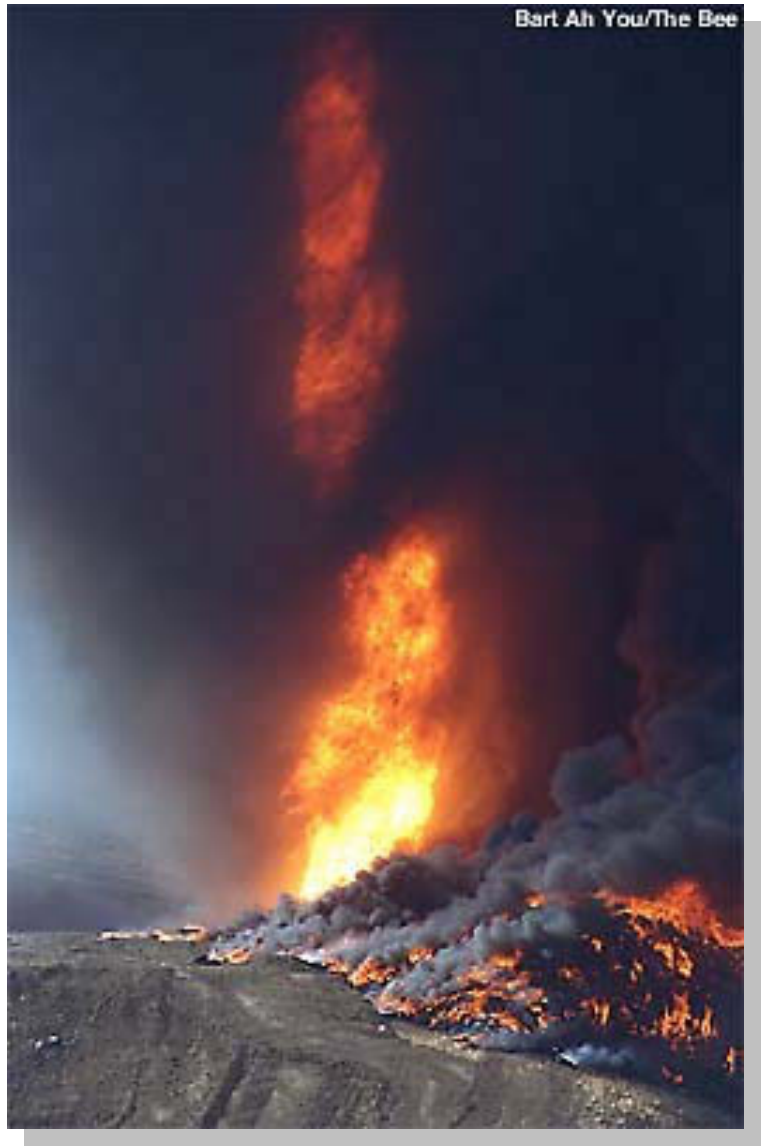




\section{Scrap Tire Generation}

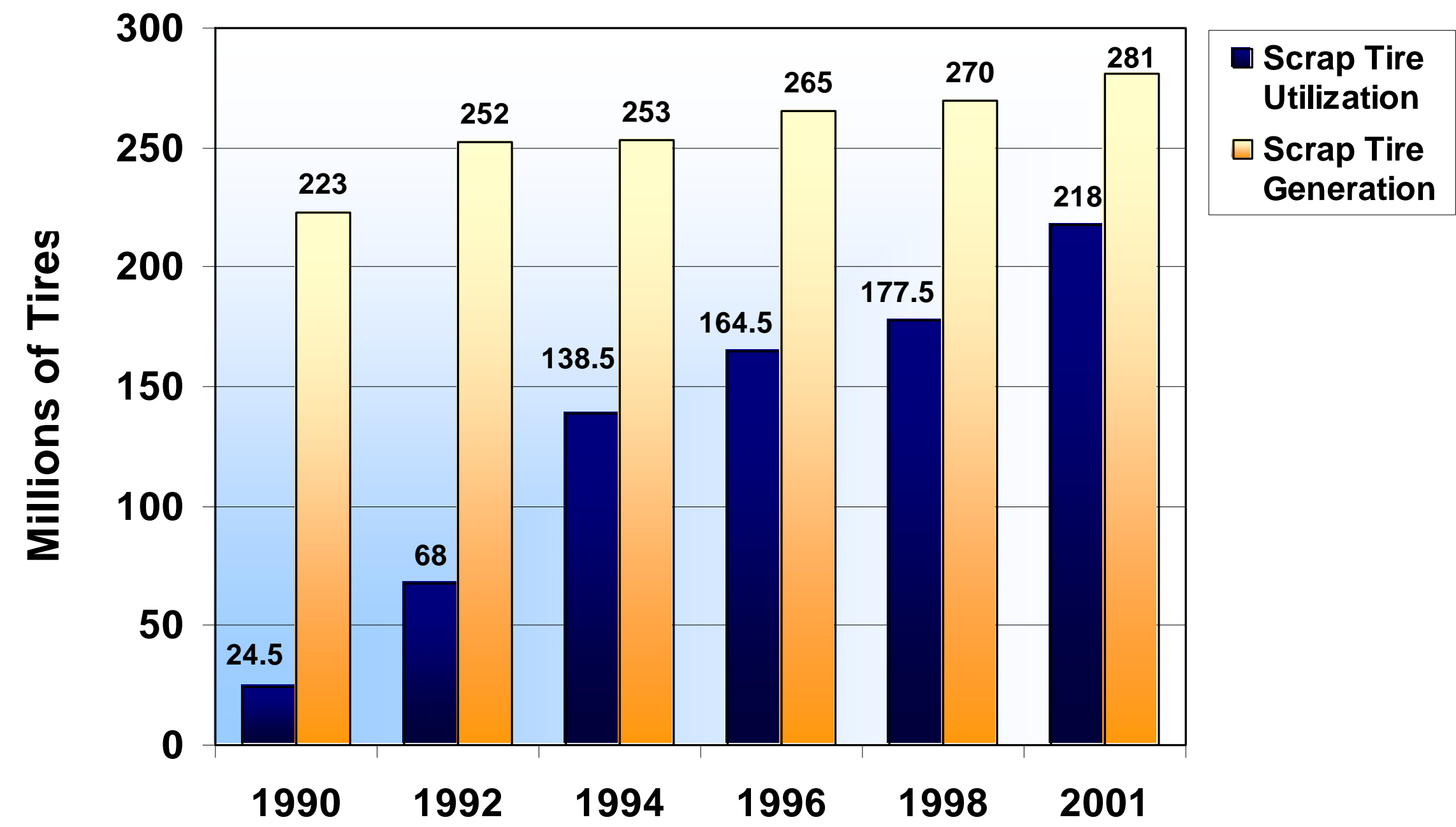




\section{Scrap Tire Utilization - 2001 281 Million Tires Total}

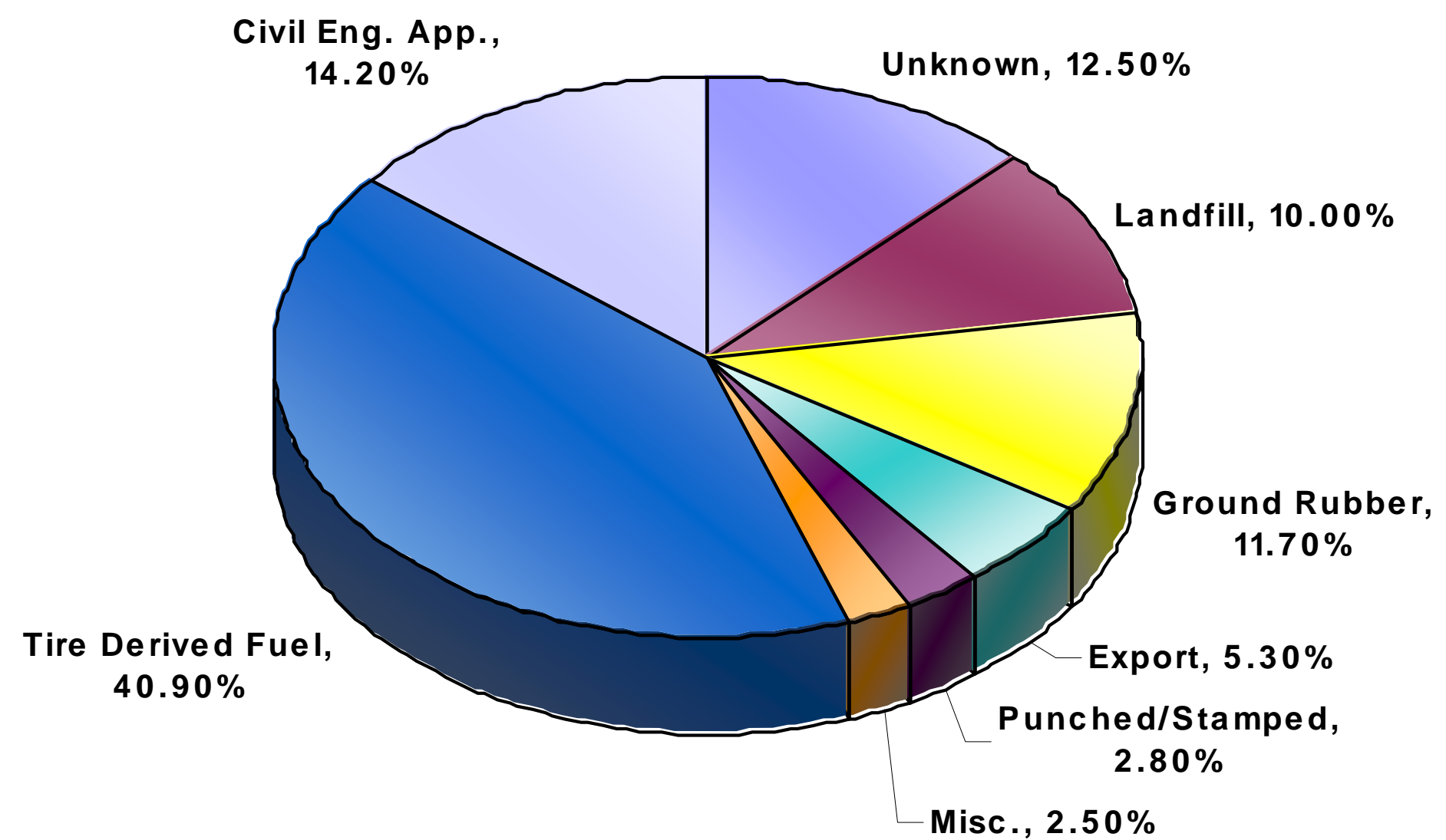




\section{State by State Programmatic Management}

- Programs for disposal and/or management are highly varied with various degrees of success

- Most states have implemented a tipping/disposal fee when new tires are purchased

- Significant number of tire piles still exist

- Cradle-to-grave mgmt not occurring for $\mathbf{2 7 . 7 \%}$ of tires generated annually

- Highly variable markets for tire disposal depending upon location

- Combustion of tires is most responsible when all factors are considered

- Not permitted in all states 


\section{Tire Derived Fuel Usage}

\begin{tabular}{|l|c|c|}
\hline \multicolumn{1}{|c|}{ TDF Market Classes } & $\begin{array}{c}1998 \\
\text { (Million Tires) }\end{array}$ & \multicolumn{2}{|c|}{$\begin{array}{c}2001 \\
\text { (Million Tires) }\end{array}$} \\
\hline Cement Kilns & 38 & \multicolumn{2}{|c|}{53} \\
\hline Utility Boilers & 25 & 18 \\
\hline Industrial Boilers & 15 & 11 \\
\hline Pulp and Paper & 20 & 19 \\
\hline Direct Tire to Energy & 16 & 14 \\
\hline
\end{tabular}




\section{Co-combustion of Tire Derived Fuel (TDF)}

- Shown to be a responsible approach with respect to emissions

- Successful TDF co-combustion is system dependent (cyclone, fluidized beds, rotary kilns, traveling grate)

- Cheap high BTU fuel additivel enhancer

- Heating value higher than some coals

- Tire: 11,500 - 16,000 BTU/lb.

- Coal: 8,500 - 13,500 BTU/lb.

- Gob coal - 7500 BTU/lb 


\section{Why Aren't More Facilities Co-firing TDF?}

- Permitting....

- Tires are classified as a solid waste

- Concern for sulfur and metals

- Retrofitting may be required...

-Economics do not justify capital investment

- Lack of sustainable market / supply...

- Impact by state tire programs

- Variable TDF quality

\section{Basis for NETL CRADA}




\section{Comparative Fuel Analysis}

Constituent

Carbon

Hydrogen

Oxygen

Nitrogen

Sulfur

Ash

Moisture $\underline{\text { Tires wt } \%}$ 83.87

7.09

2.17

0.24

1.23

4.78

0.62

15,500
Coal wt\%

73.92

4.85

6.41

1.76

1.59

6.23

5.24

Btu/Lb.

13,000 


\section{EPA Report on TDF}

- "TDF has long been recognized as a potential fuel. It compares favorably to coal. It has higher heating value, less moisture, more carbon, about as much sulfur as medium sulfur coal, but much less fuel-bound nitrogen." --EPA 1997 report: "Air Emissions From Scrap Tire Combustion"

- EPA Research Center kiln simulation test:-- (EPA 1997 report) "It is concluded that, with the exception of zinc emissions, potential emissions from TDF are not expected to be very much different than from other conventional fossil fuels, as long as combustion occurs in a well-designed, well-operated and well-maintained combustion device. If unacceptable particulate loading occurs as a result of zinc emissions, an appropriate particulate control device would need to be installed*".

- Experiences show that with high-efficiency PM control devices, such as a bag filter, zinc emissions from TDF can be controlled to the same level as when solely using coal. 


\section{U.S. DOE NETL Tire CRADA - Part 1}

- Goal: Offer alternative for the support of a sustainable market and consistent TDF quality

- Issues:

- High costs in transporting and processing tires into TDF

- Tipping fee varies greatly but key to suitable profit margin

- Inconsistent TDF quality - problematic for end user

- Idea: Mobile unit capable of processing tires on site thus allowing the transportation of high volume of tires to fuel depot with less equipment, labor, and overall cost

- Targeted market: Retail 


\section{Mobile Unit Concept}

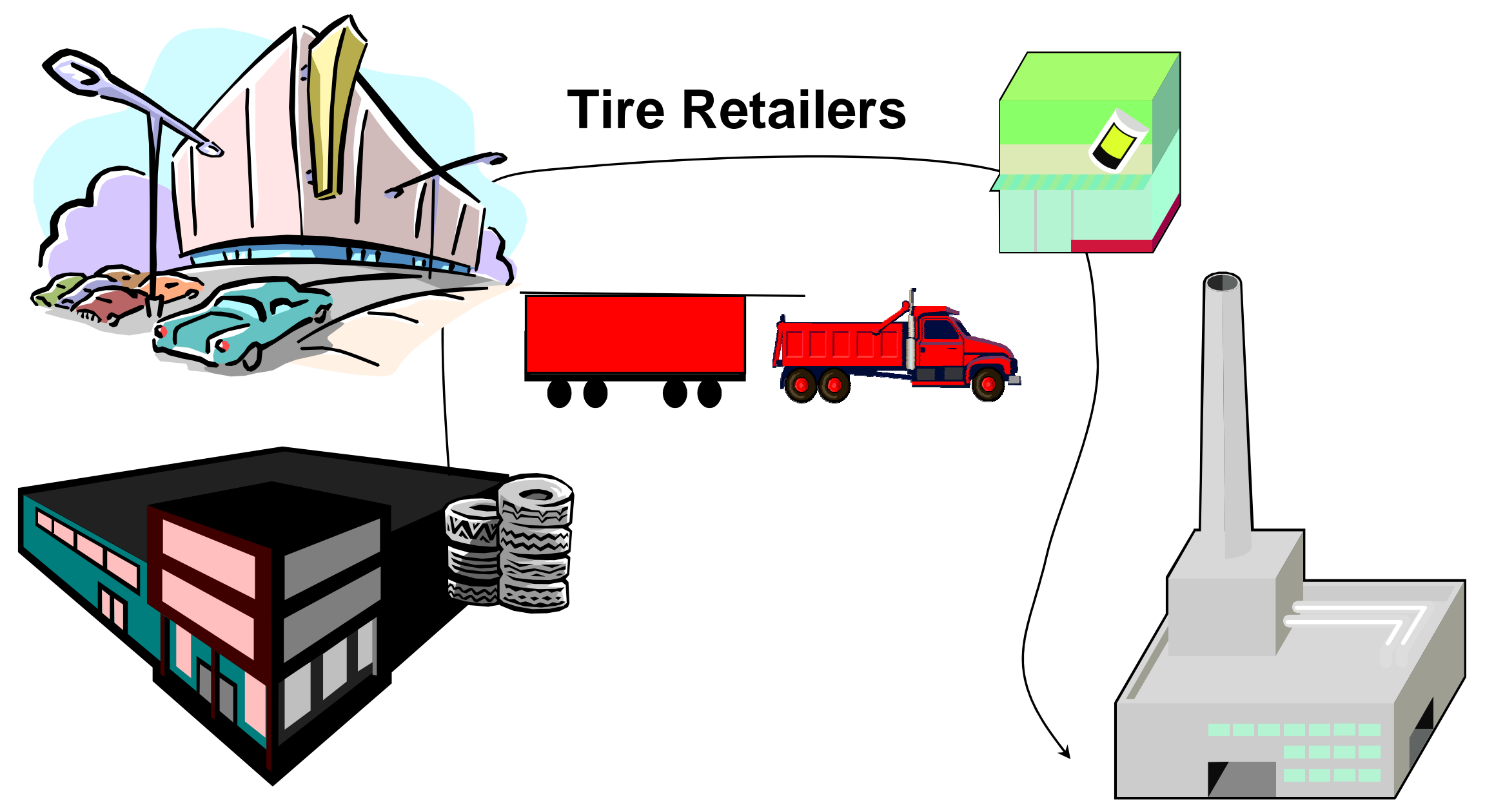

NETL

End user: Utility 


\section{Mobile Processing Unit}

- Dump truck with suitable hydraulic system

- 16' trailer with processing equipment

-2 tires per minute (design time)

-Production of 1"x1" wire in chips

- Slicer, chopper, chipper, and conveyor

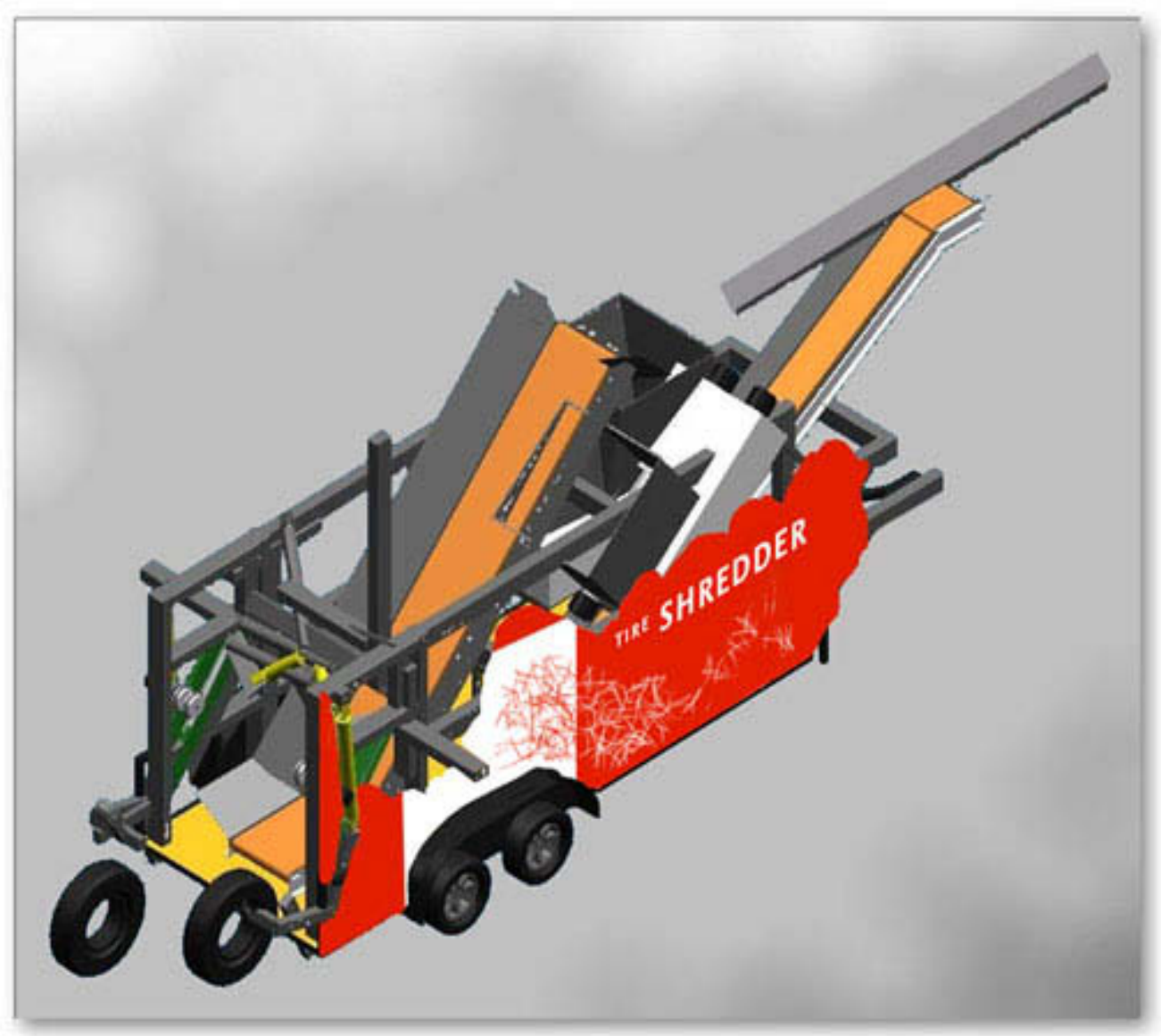




\section{Mobile Unit Design}

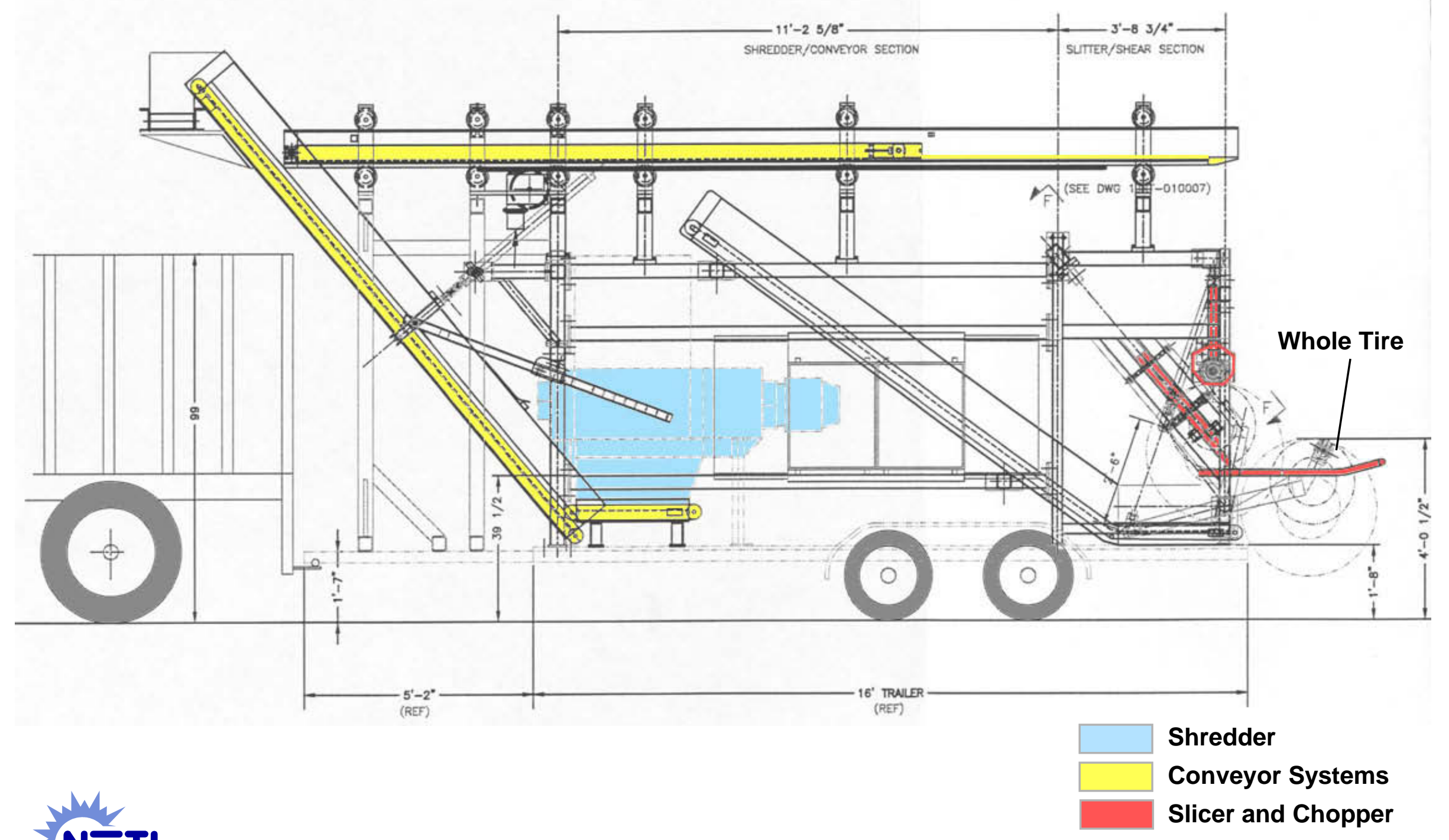

NETL

175620 DLB 03/10/03 


\section{Generalized / Conservative Economic Evaluation}

- Fixed assumptions:

$-\$ 15.00 /$ ton TDF

- $\$ 500,000$ purchase cost (truck \& mobile shredder)

- Sale of TDF to cover maintenance expenses

- Approximately \$1.75 tipping fee needed to break even on a single unit

-5.5 hours of daily operation

- Less the distance and higher number of tires per location result in higher ROI

- Balance maintenance costs with fuel costs

- Other scenarios under evaluation

- e.g. single customer daily, weekly delivery to facility 


\section{Economic Evaluation of Mobile System}

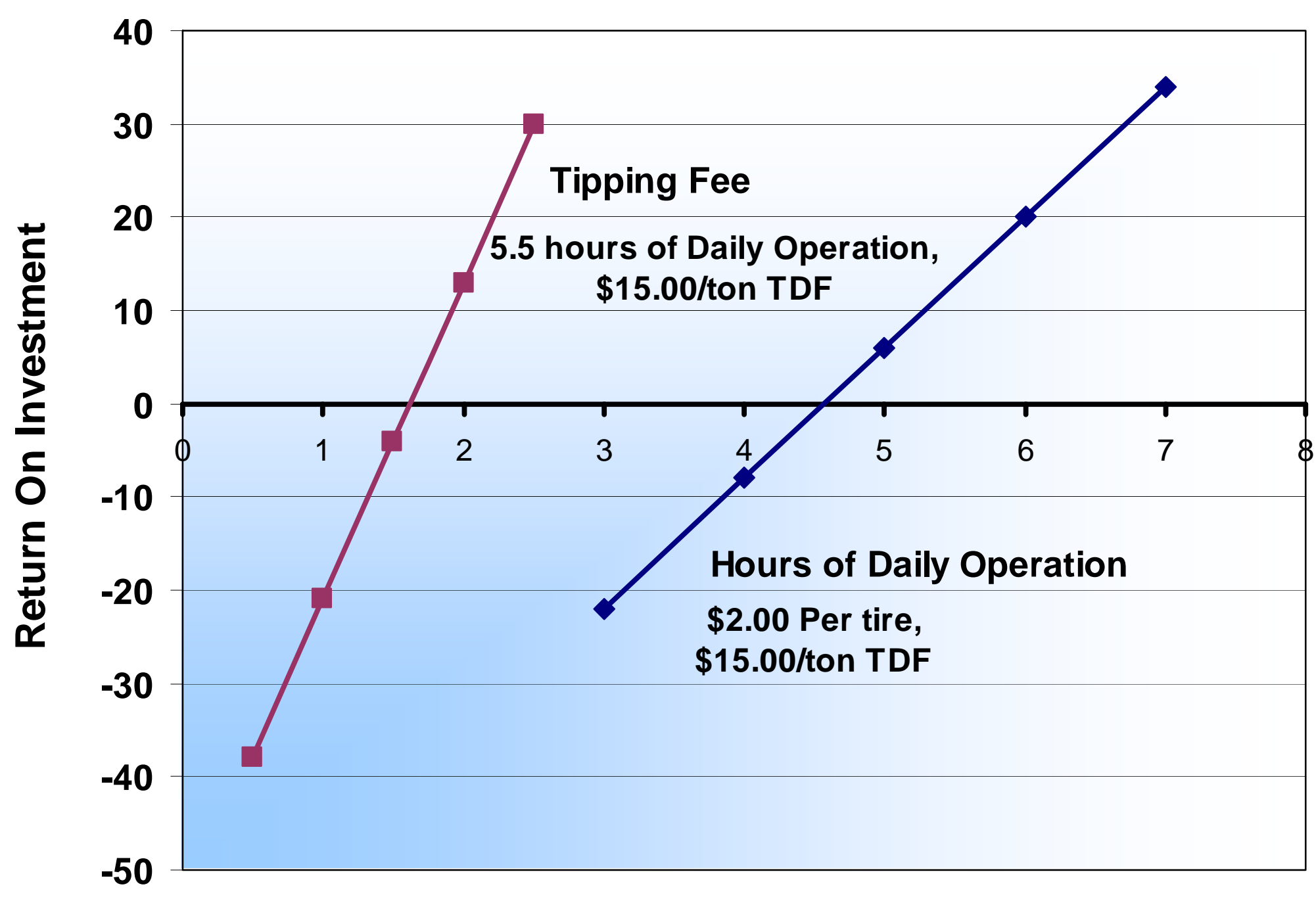




\section{TIRE CRADA - Status}

- Design completed

- Plan developed for fabrication and routing demonstration

- Continue to evaluate economics

- Seeking additional funds / CRADA partners including site for co-combustion of TDF

- Initiate evaluation permitting requirements in near future 


\section{Summary}

- Use of TDF by Utilities is decreasing

- Opportunity to improve and expand TDF production and utilization exists

- Mobile tire chipping equipment offers economic approach

\section{Contact Information}

Don Bonk, Advanced Combustion Product

Manager, 304-285-4889

Susan Maley, Project Manager, 304-285-1321 


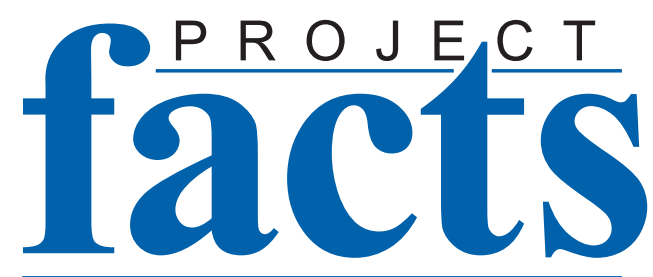

U.S. DEPARTMENT OF ENERGY

OFFICE OF FOSSIL ENERGY

NATIONAL ENERGY TECHNOLOGY LABORATORY

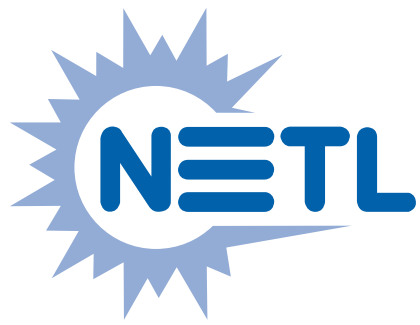

\section{CONTACT}

Donald L. Bonk

Product Manager

Combustion Technologies

U.S. Department of Energy

National Energy Technology

Laboratory

304-285-4889

304-285-4469 fax

donald.bonk@netl.doe.gov

\section{PARTICIPANTS}

\section{JanRT Tire Recycling}

Equipment, LLC

Muncie, Indiana

\section{Mary Ellen Corporation}

Bridgeport, West Virginia

\section{CUSTOMER SERVICE}

800-553-7681

\section{WEBSITE}

www.netl.doe.gov/coalpower/ combustion/

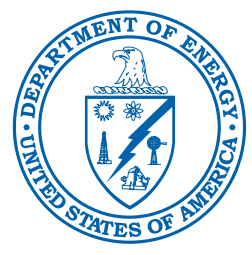

\section{Co-Firing Tire-Derived Fuel Advanced Combustion Systems}

\section{Description}

To help mitigate the nation's scrap tire problem, a Cooperative Research and Development Agreement (CRADA) was created between NETL and two small businesses: JANRT Tire Recycling Equipment, LLC of Muncie, Indiana and Mary Ellen Corporation of Bridgeport, West Virginia. This CRADA was awarded to develop and demonstrate a prototype portable tire chipper which would turn scrap tires into small pieces of rubber to be used as supplemental fuel to co-fire with coal in Fluidized-Bed Combustion Systems (FBC) and other types of furnaces. Tire chips have been shown to enhance the combustion of these systems rendering them more efficient. As such, it is a highly desirable additive for coal-fired systems.

Scrapped tires are currently a significant environmental problem. In the U.S. alone:

- 281,000,000 tires are discarded annually, one for every man, woman, and child.

- 23 percent of these scrap tires are stockpiled, or just dumped.

Stockpiled and dumped tires are an unsightly breeding ground for mosquitoes and play a key role in sustaining the threat to public health brought about by the diseases spread by mosquitoes. In addition, the tire piles are considered a severe fire hazard which could potentially burn out of control. In the past, some large scrap tire fires have burned for weeks resulting in tremendous amounts of toxic air pollution.

This CRADA, in which the partner receives no Federal funds but agrees to match Federal expenditures in order to achieve a common goal, would study the commercial feasibility of a portable trailer-mounted tire chipping system. NETL is currently evaluating the economic merits of co-firing these tire chips.

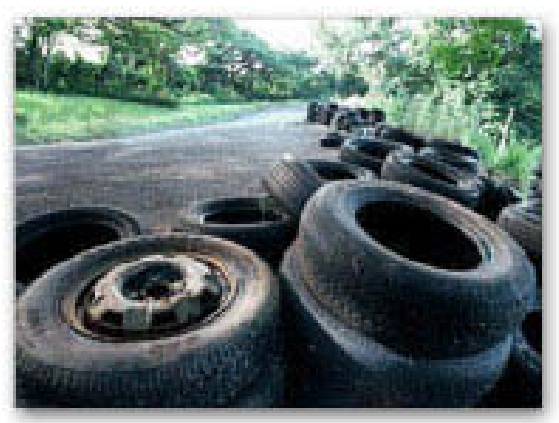




\section{Co-Firing Tire-Derived Fuel Advanced Combustion Systems}

\section{Benefits}

The potential benefits of the CRADA and co-firing tire-as-fuel are four fold:

- A viable economic solution to a serious environmental problem (tire piles) is offered.

- Business opportunity for CRADA partners and other small business as well as power producers is created.

- The use of coal is enhanced with respect to stabilized, more efficient combustion and lower net emissions per BTU.

- A low cost fuel additive / enhancer is made available to suitable coal-fired systems.

This Project CRADA helps communities to recycle its worn tires, and avoid the current environmental problems they cause. Recycling tires in this manner provides a renewable electricity source.

Tire collection fees and sale of the tire-derived chipped fuel offset the cost to chip and deliver them to the power plant. There is potential for a small business to be developed around this CRADA-derived product.

Circulating Fluidized-Bed Combustion Systems (CFB) and many other conventionally fired solid combustion furnaces can co-fire chipped tires, so long as the proportion of chips is under about 20 percent of the Btu load to the boiler. Tires make an outstanding clean fuel for electric power generation. In furnaces with proper combustion control, scrap tire chips: undergo controlled combustion and do not generate the toxic fumes associated with open burning of tire piles, provide a high energy content fuel ( 14,000 BTU/lb), and stabilize the coal combustion process.

The use of tire chips is so efficient at stabilizing the combustion process in furnaces that utilize inconsistent lowgrade solid fuel that is a preferred approach. Boiler efficiency may increase slightly when chipped tires are burned.

\section{Product of the CRADA}

- Prototype of mobile tire chipping equipment designed and constructed.

- Demonstration of equipment via a local route which processes and delivers tire to an end user.

- An economic analysis of the proposed mobile process.

- An evaluation of the equipment and environmental permit modifications necessary to co-fire tire as fuel.

- Assistance in the communication of the benefits of tire recycling.

\section{Technical Readiness}

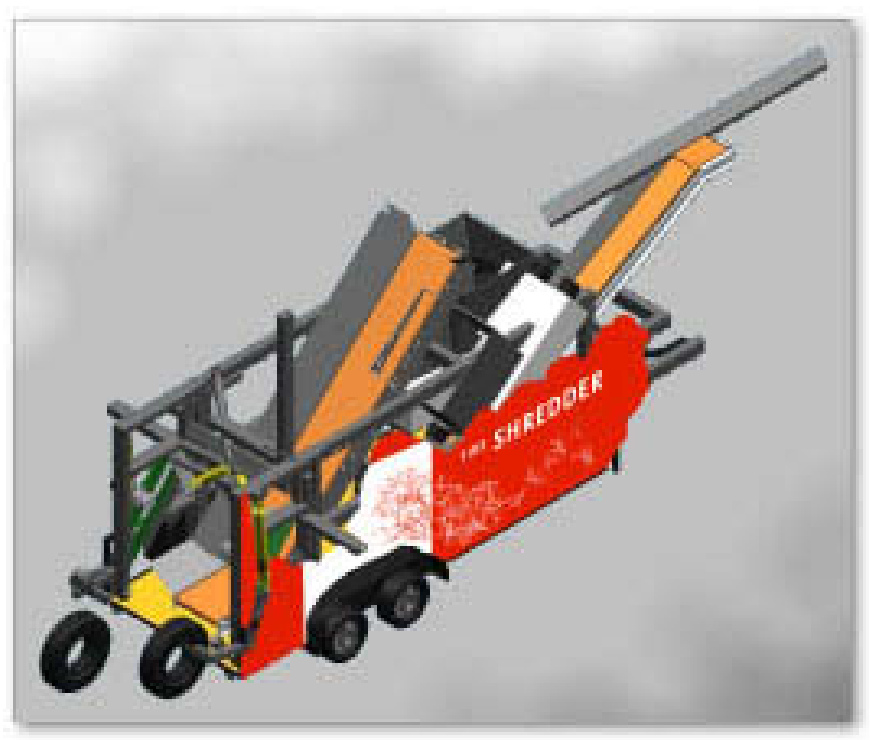

The primary risk for the project is assuring that the mobile tire shredding equipment and the manner is which it is used will result in an adequate return on investment for the owner and operator of the system. The economics of the system depend highly on the proximity in which the mobile equipment must travel to process the tires and transport the tire derived fuel to the end user as well as the fees to processing the tire and purchase price of the fuel. Technical risk for making mobile chipping equipment is low. Co-firing chipped tires has proven successful, and the feed and combustion control needed are known. Full-scale testing is needed to work out the equipment and infrastructure influences on overall economics. The mobile chipper system is in detail design, and fabrication is underway. Soon, the chipping testing will begin. After that, combustion co-firing testing will take place. With success, a new business will be launched. 


\title{
Attachment C: \\ Tire-Derived Fuel: Key Considerations for Power \\ Generation Systems and Industrial Boilers \\ CRADA No. 01-N044
}

\author{
Susan Maley \\ National Energy Technology Laboratory \\ 3610 Collins Ferry Road \\ Morgantown, WV 26505
}

March 31, 2004
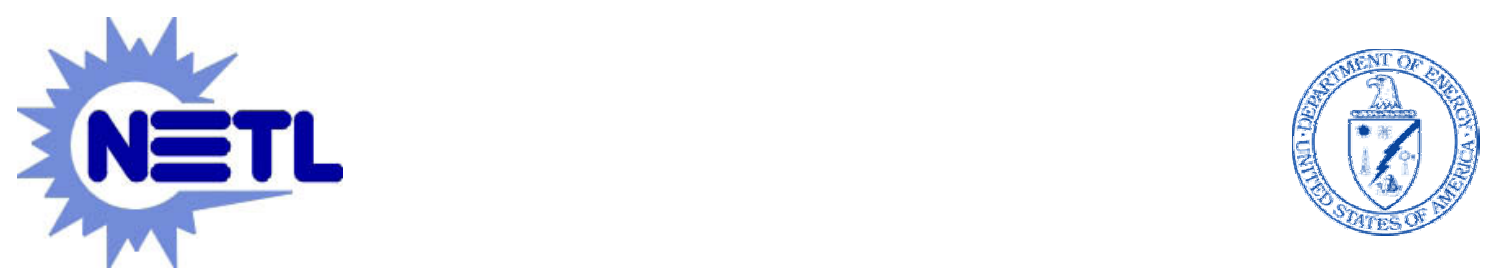


\section{Disclaimer}

This report was prepared as an account of work sponsored by an agency of the United States Government. Neither the United States Government nor any agency thereof, nor any of their employees, makes any warranty, express or implied, or assumes any legal liability or responsibility for the accuracy, completeness, or usefulness of any information, apparatus, product, or process disclosed, or represents that its use would not infringe privately owned rights. Reference therein to any specific commercial product, process, or service by trade name, trademark, manufacturer, or otherwise does not necessarily constitute or imply its endorsement, recommendation, or favoring by the United States Government or any agency thereof. The views and opinions of authors expressed therein do not necessarily state or reflect those of the United States Government or any agency thereof.

\section{Acknowledgments}

This report was prepared by the United States Department of Energy's National Energy Technology Laboratory in support of CRADA No. 01-N044, Co-Firing Tire-Derived Fuel.

A substantial amount of supporting information came from Parsons. The author wishes to acknowledge the excellent cooperation of Parsons, particularly Mike Klett and Joe Takats 


\section{Acronyms and Abbreviations}

ASTM American Society for Testing and Materials

Btu British thermal unit

LLC limited liability corporation

LOI loss on ignition

MW megawatt

NSR New Source Review

NOx oxides of nitrogen

OEPA Ohio Environmental Protection Agency

PA DEP Pennsylvania Department of Environmental Protection

PSC Public Service Commission

$\mathrm{SO} 2$ sulfur dioxide

TDF tire derived fuel

WV DEP West Virginia Department of Environmental Protection

WV DOH West Virginia Department of Highways

Wt. \% weight by percent 


\section{Contents}

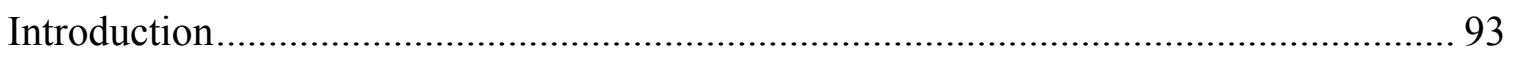

Considerations for Using Tire-Derived Fuel (TDF) ……………………….................. 93

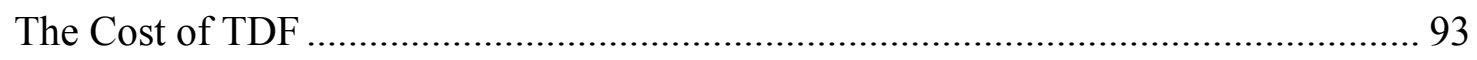

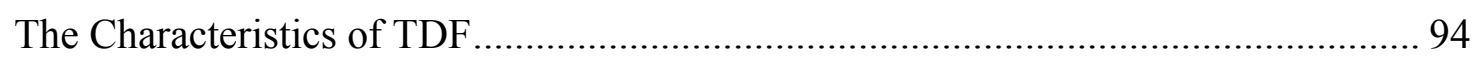

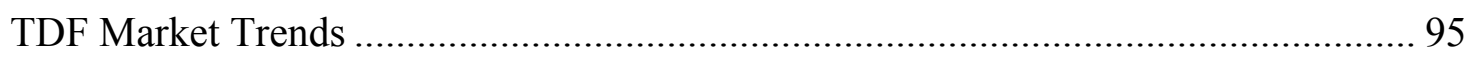

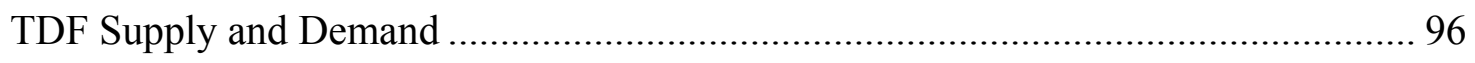

Benefits and Impacts From Using TDF ....................................................................... 97

Overview of State Scrap Tire Management Programs …………..................................... 98

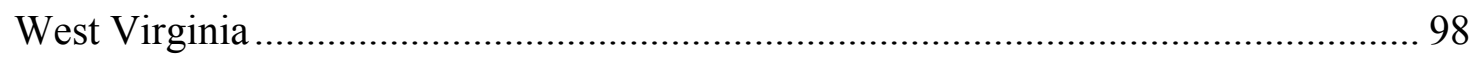

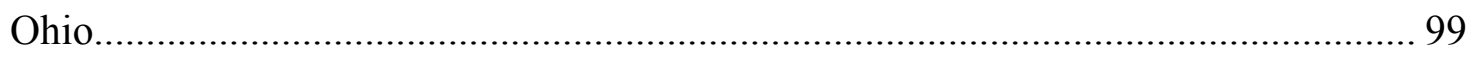

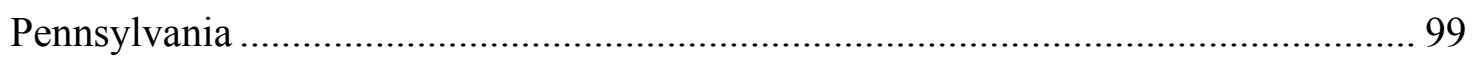

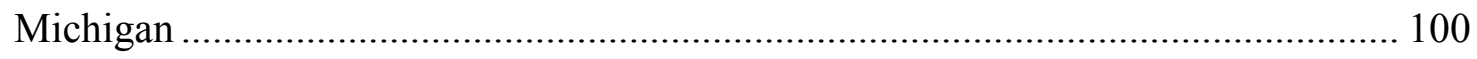

Regulatory Considerations for Using TDF as a Supplemental Fuel............................... 101

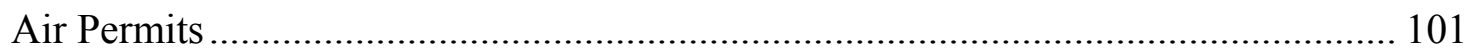

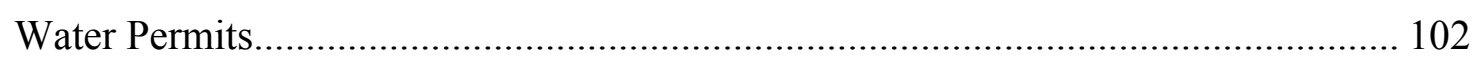

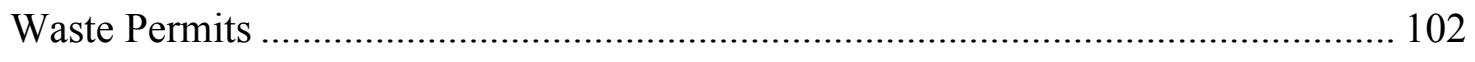

Regional Analysis of Using TDF: Air Quality Regulatory Considerations ............... 103

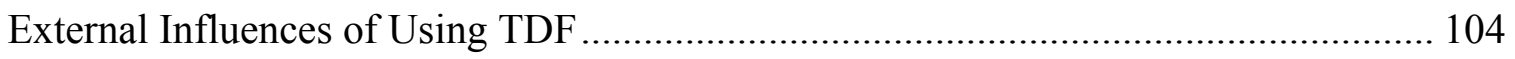

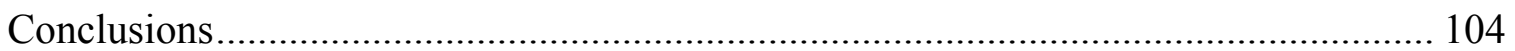

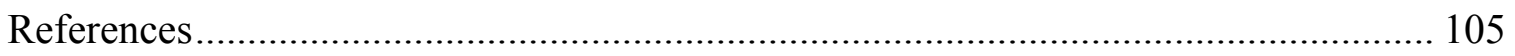

\section{Figures and Tables}

Table 1. Average Cost of Fossil Fuels for Electric Utilities [2] ...................................... 94

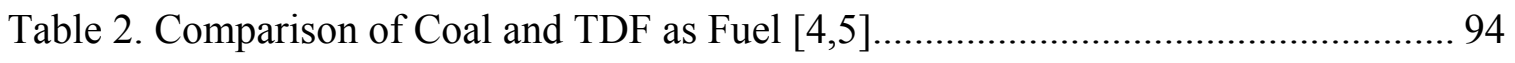

Figure 1. Utilization of Tire Derived Fuel by Industry.................................................. 95

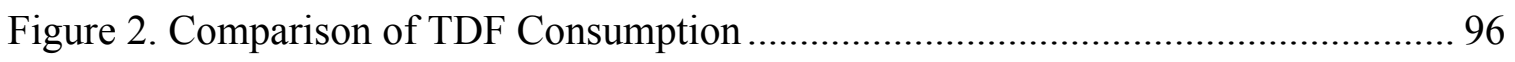




\section{Introduction}

State recycling and end use programs appear to be successfully managing approximately 78 percent of the 281 million scrap tires generated annually [1]. While several acceptable end uses have been identified for waste tires, a significant number are still being accumulated, monofilled, or mismanaged. From an environmental and energy standpoint, the use of scrap tires as fuel for energy production is a viable option with ample growth opportunity, but the amount of tires consumed for power production is declining. This report examines the key considerations and related issue of using tirederived fuel (TDF) as a supplemental fuel for coal-fired steam and power generation facilities.

This report discusses fuel cost, supply and demand, and characteristics of TDF for use in power generation facilities, as well as regulatory considerations and external influences. Having properly considered these factors, a steam or power producer can legitimately consider TDF as a means to lower fuel costs, enhance the overall efficiency of a system, and meaningfully contribute to the environmental management of a region.

\section{Considerations for Using Tire-Derived Fuel (TDF)}

\section{The Cost of TDF}

Reducing operating costs at a particular facility is the primary driver for using TDF. The cost of TDF is variable and depends upon the amount of processing associated with turning whole tires into TDF, transportation, and the way in which the individual states implement their scrap tire management program. The cost of TDF ranges from $\$ 10$ to $\$ 32 /$ ton of TDF, or $\$ 0.37$ to $\$ 1.19 / 10^{6}$ Btu. In general, the cost of transporting TDF a distance of less than 150 miles can be balanced against the fuel price, so that TDF is a cost competitive option. Removing wire from the tires, and reducing tires to the proper size for co-firing represent the highest processing costs; the smaller the chip, the higher the price of the fuel. Leaving the wire in the processed TDF can also save on processing costs, if the facility is equipped to handle the wire. A 1-inch chipped, wire-in TDF is approximately $\$ 15$ per ton; average. Long-term contracts can be negotiated to offer incremental savings over the current market price.

The scrap tire management program implemented by each state has a direct impact on the cost of TDF. Steam and power generation facilities considering TDF should become familiar with the state's payment or reimbursement structure relating to the processing, supply, and handling of TDF. For example, costs can be near zero in states where the end user is reimbursed for documented recycling or consumption of the scrap tires.

Reimbursements can cover the cost of transporting and processing whole tires into TDF. For example, select cement kilns have profited from this type of program, because their systems were retrofitted to co-fire whole tires thus avoiding processing costs associated with TDF. Selected state management programs and costs are discussed in more detail on page 98

Table 1 provides the average cost of commonly used fossil fuels for power generation. By weight, TDF has a higher heating value, ranging from 12,000 to 15,000 Btu per pound 
and costs less than or equivalent to coal. Equivalents weights of different types of coal can have heating values that range from 7,500 to 13,500 Btu per pound. One tire is roughly equivalent to 2.5 gallons of oil, or 285 cubic feet of natural gas. While financial benefits for power generation facilities are apparent, positive environmental benefits are also achieved by a reduction in the total amount of pollutants generated on a per-ton-fuel basis.

Table 1. Average Cost of Fossil Fuels for Electric Utilities [2]

\begin{tabular}{|c|c|c|c|c|}
\hline Year & Coal $^{*}$ & Coal* & Petroleum** & Natural Gas \\
\hline & \$/ton & Cents $/ 10^{6}$ Btu & Cents $/ 10^{6} \mathrm{Btu}$ & Cents $/ 10^{6}$ Btu \\
\hline 2001 (Average) & 24.67 & 123.15 & 369.27 & 448.65 \\
\hline 2002 (Average) & 24.74 & 121.81 & 325.13 & 367.02 \\
\hline 2003 (Jan-May) & 25.55 & 124.68 & 447.46 & 593.19 \\
\hline
\end{tabular}

* Coal includes: Anthracite, bituminous coal, subbituminous coal, lignite, waste coal, and synthetic coal.

** Petroleum fuel includes: Distillate fuel oil, residual fuel oil, jet fuel, kerosene, petroleum coke, and waste oil.

Data reproduced from EIA Table 4.2 "Receipts, Average Cost, and Quality of Fossil Fuels: Electric Utilities, 2001 through May 2003, available on their website: www.eia.doe.gov.

While these comparisons are favorable for TDF, a facility considering using TDF as a supplemental fuel is best served by a direct comparison between their coal and the local supply of TDF for a pertinent cost comparison.

\section{The Characteristics of TDF}

In addition to the cost and BTU comparisons, an analysis of a facility's coal compared to TDF should be made in order to assess the potential positive or negative impacts on a system's operation and emissions. This data can also be used to estimate the amount of TDF to be co-fired by the facility. Table 2 provides a comparison of TDF and bituminous coal. Because of the interest in using TDF, ASTM developed a sampling and analysis protocol [3]. ASTM protocol also included analyses of TDF and comparison with other fuels commonly used by utilities and industrial boilers.

Table 2. Comparison of Coal and TDF as Fuel $[4,5]$

\begin{tabular}{|l|l|l|l|l|l|l|l|}
\hline \multicolumn{1}{|c|}{ Fuel } & $\begin{array}{c}\text { Heating } \\
\text { Value } \\
\text { (Btu/lb) }\end{array}$ & $\begin{array}{c}\text { Carbon } \\
\text { Wt. \% }\end{array}$ & $\begin{array}{c}\text { Hydrogen } \\
\text { Wt. \% }\end{array}$ & $\begin{array}{c}\text { Oxygen } \\
\text { Wt. \% (by } \\
\text { difference) }\end{array}$ & $\begin{array}{c}\text { Nitrogen } \\
\text { Wt. \% }\end{array}$ & $\begin{array}{c}\text { Sulfur } \\
\text { Wt. \% }\end{array}$ & $\begin{array}{c}\text { Ash } \\
\text { Wt. \% }\end{array}$ \\
\hline Bituminous coal & 14,000 & 81.4 & 5.0 & 4.7 & 1.4 & 1.5 & 6.0 \\
\hline $\begin{array}{l}\text { Subbituminous } \\
\text { coal }\end{array}$ & 9,000 & 52.5 & 6.2 & 29.5 & 1.0 & 1.0 & 9.8 \\
\hline Anthracite coal & 12,700 & 80.0 & 2.9 & 5.0 & 0.9 & 0.7 & 10.5 \\
\hline Lignite coal & 6,900 & 40.1 & 6.9 & 44.0 & 0.7 & 1.0 & 7.3 \\
\hline TDF w/ steel & 14,495 & 69.90 & 6.75 & 4.8 & 0.34 & 1.35 & 16.91 \\
\hline TDF w/o steel & 15,781 & 81.70 & 7.18 & 3.26 & 0.56 & 1.62 & 5.68 \\
\hline
\end{tabular}




\section{TDF Market Trends}

A reliable fuel supply is another important consideration that should be examined on a regional basis since it varies by state and region. The Rubber Manufacturers Association issues a bi-annual report on the U.S. scrap tire market, which examines the usage of TDF across the country. In 2001, approximately 115 million tires were consumed as TDF in various industries [1]. A breakdown of the TDF consumption by industry is shown in Figure 1 below.

115 Million Tires Total consumed in 2001

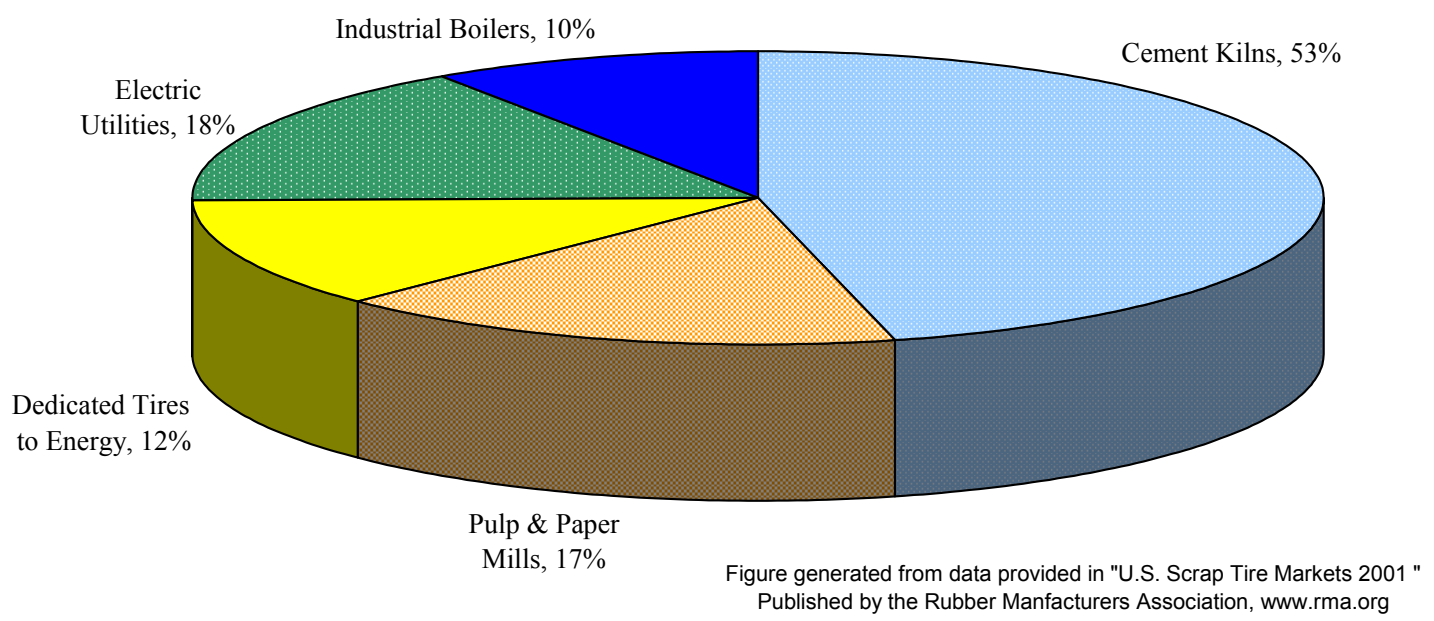

Figure 1. Utilization of Tire Derived Fuel by Industry

While the amount of TDF consumed annually has remained stable since 1996, the amount consumed by utilities and industrial boilers has declined from 39 to 40 million tires in 1996 and 1998, to 29 million tires in 2001. (See Figure 2.) The Rubber Manufacturers Association surmises that this decrease is related to the deregulation of the utility industry, the lowering of emission limits for criteria pollutants, and the potential for opening the facility to a New Source Review (NSR) [6].

Utility deregulation has brought about the sale and closure of facilities, which was closely related to the cost of complying with environmental regulations for older units. 


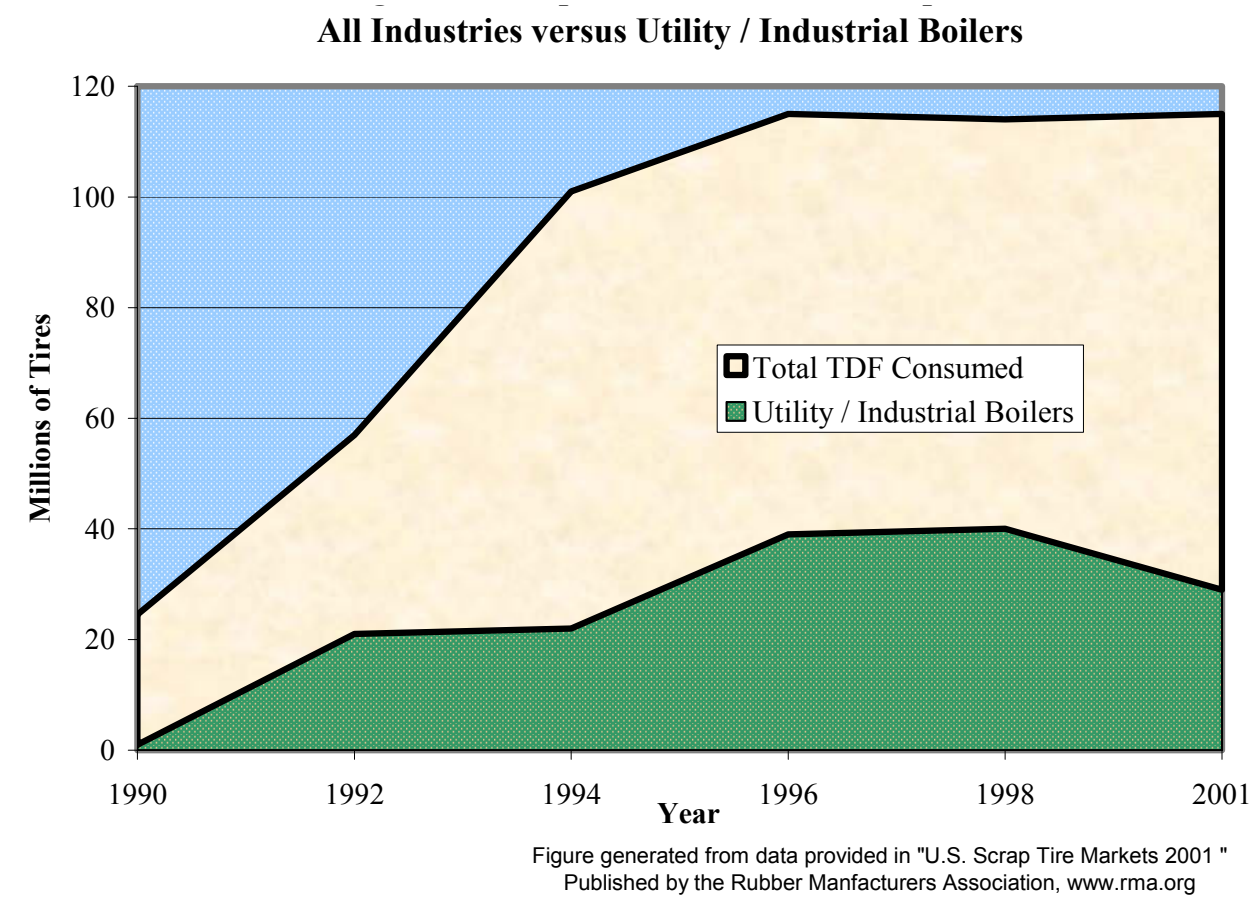

Figure 2. Comparison of TDF Consumption

It is not clear how the pending regulations will ultimately impact the use of TDF by a deregulated utility industry. A deregulated market would appear to embrace an alternative fuel that is competitively priced with coal, offers a higher Btu value, lower variability in quality, and offers potential to lower emissions. Despite apparent market opportunities, steam and power generation facilities must operate within the federal and state air quality regulations, which impose stricter limits on emissions, regardless of the fuel. Amending permits is not easily accomplished, even if switching fuel does not affect emissions levels. Stringent air quality regulations might make steam or power generation facilities reluctant to experiment with or introduce alternative fuels.

\section{TDF Supply and Demand}

Generally, the number of tires available for conversion to TDF is greater than the demand for fuel. Tire processors must be responsive to the demand for specific fuel specifications, while complying with scrap tire management program regulations. The fees charged for the collection and transportation of tires range from $\$ 0.50$ to $\$ 2.50$ per tire, and are usually sufficient for handling tires, but may not be enough to sustain processing and delivery costs. While tire processing equipment has improved, it still remains an energy intensive process, and a balance between effort and cost must be maintained to keep processing, delivery, and fuel prices competitive. This balance can be achieved when the size of the TDF is around $1 \mathrm{inch}$. Removing wire from the tire increases processing costs, but is generally preferred by power generators to reduce the potential for operational interferences. However, 1-inch wire-in chips have been successfully used, if the chips are clean cut and free of residual or lagging wires. 
Despite the narrow profit margins that exist in the TDF market, a stable supply has emerged in regions where cement kilns and other industries are continuously using TDF as a supplemental fuel. Facilities considering TDF would benefit from knowing the existing supply and demand of the region. In places where a suitable supply is not available, a reasonable time should be given to establish a supply before continuous cofiring of TDF is initiated.

\section{Benefits and Impacts From Using TDF}

A complete analysis of TDF shows its similarity to coal, except for the presence of zinc ( $\sim 1.5 \%$ by weight). Compared to coal, TDF has more volatile matter, lower moisture, lower fuel bound nitrogen, and is more homogeneous. This can result in an incremental increase in efficiency and lower $\mathrm{NO}_{\mathrm{x}}$ emissions. The proper combustion of TDF can also lower other emissions (e.g., $\mathrm{SO}_{2}$ and particulates) on a relative baseline comparison. Complete combustion of the TDF can also result in a lower LOI content of fly ash.

However, these benefits must be weighed against potential operational interferences, such as plugging of the ash removal system from residual wire, and changes in the ash due to the presence of zinc and iron oxide (if wire-in chips are used). More important, the negative impacts from incomplete combustion of TDF can be significant and can include increases in particulate emissions, emission of non-traditional trace pollutants, and ash with high carbon content. Changes to the resistivity of the high carbon ash containing zinc and or iron oxide can impact the collection efficiency of the particulate control device (e.g., an electrostatic precipitator).

To avoid common operational problems, the amount of TDF co-fired with coal has ranged from 2 to 20 percent of the total Btu. The range is determined by the design of the fuel feed and boiler systems, and operating experience. An existing system capable of feeding large diameter fuel is preferred along with the ability to blend with coal such that retrofits are not required. The boiler's ability to accept larger sized fuels is important, since TDF can be readily produced in the form of 1-inch chunks. Systems capable of feeding larger sized fuels include: fluidized bed boilers, cyclone boilers, and stoker/grate type boilers. The combustion system must also have sufficient residence times and high firing temperatures to ensure complete combustion of the blended fuel. Generally, gas residence times should be on the order of tens of milliseconds, with firing temperatures of at least 1,500 to $1,600^{\circ} \mathrm{F}$. These conditions are commonly found in fluidized bed and cyclone boiler systems.

Steam or power producers would not likely use TDF if modifications to their system are required, because the investment would likely cancel out any savings from using a lower cost fuel. In this case, it is important to develop a fuel specification for TDF in which equipment modifications and increases in maintenance are minimized or avoided, such as specifying the largest acceptable fuel size, and considering the presence of wire in the fuel. Harding (2002) provides an analysis of different types of TDF and ash at different facilities. It is important to note that a large variability exists in the performance improvements and challenges experienced at different facilities. Individual testing and analysis is necessary, since each power generation facility is unique. A review of past performance suggests that co-firing a small percentage $(<10 \%$ of total heating value) of wire-free 1 -inch by 1 -inch TDF results in a reduction of criteria pollutant emissions, with 
slight changes to the parameters of the particulate collection device (due to the presence of zinc), but maintains high collection efficiencies, and no change in the classification of ash and slag.

Hence, if a steam or power generation facility meets the criteria for co-firing larger sized fuel, an optimum blending rate, and fuel specification can be determined to obtain the benefits, and avoid the operational challenges of co-firing TDF.

\section{Overview of State Scrap Tire Management Programs}

Almost every state has a program in place to oversee the generation and management of scrapped, abandoned and stockpiled tires [7]. While program structures and implementation methods vary from state to state, the majority of the abandoned and stockpiled tires have been successfully remediated through these programs. These cleanup efforts have been supported primarily through the collection of taxes or fees attached to the sale of new tires.

Several beneficial uses for tires have been identified and are supported by state programs. However, establishment of large and sustainable markets remains the greatest challenge. Programs in Louisiana and Virginia were recently recognized by Scrap.org for their success in establishing strong markets for waste tires and providing for the management of both the ongoing generation of scrap tires and clean up of the abandoned tire piles [8]. While the programs differ in many respects, the common thread of these programs is that reimbursements are paid directly to those who dispose of the tires, rather than those who transport them. Reimbursements are paid from funds collected from the sale of new tires, which was key to the successful recycling and creation of beneficial markets for scrap tires. Verification processes have minimized the occurrence of improper and illegal disposal.

An overview of the programs in West Virginia, Ohio, and Pennsylvania are discussed below because of the relatively large number of scrap tires generated annually or remaining stockpiles in these states, a good opportunity exists to increase the percentage of tires processed or recycled for beneficial uses, and these states also have a number of coal-fired boiler systems that could potentially use TDF. However, in West Virginia, Ohio, and Pennsylvania, only one coal-fired power generation unit is currently using TDF as a supplemental fuel. These states are also nearing the end of their major cleanup efforts for abandoned and stockpiled tires, and should proactively be supporting sustainable markets for the ongoing generation of scrap tires.

The scrap tire program managed by the state of Michigan is also highlighted since it has been very successful in managing waste tires by consuming them as TDF and offers a good example for establishing and sustaining a TDF market.

\section{West Virginia}

Scrap tire management is handled by the West Virginia Department of Environmental Protection (WV DEP) Office of Waste Management, the Public Service Commission (PSC), and the WV Department of Highways (WV DOH). The WV DEP executes the overall program, issues permits, and inspects facilities that process scrap tires. The WV 
DEP initially classifies whole tires as a solid waste and bans the incineration of solid wastes. However, once tires are processed into TDF they are rendered a fuel, thus permitting co-firing.

The Public Service Commission oversees licensing and transportation of tires, and restricts the haulers fees to the cost of transportation and disposal. This fee, usually ranging from $\$ 1.00$ to $\$ 2.50$, is paid by the public through tire retailers, and is transferred directly to the transporter. Another $\$ 0.50$ on the sale of new tires is charged for the state's general fund.

The largest disposal outlet for tires in WV is a monofill for long-term storage. Some tires are shipped out of state, and a very small percentage is sent for beneficial use. The WV $\mathrm{DOH}$ is responsible for tire cleanup, and sponsors an annual amnesty program to collect tires from private citizens. A $\$ 5$ fee is charged when titling vehicles in WV and is used specifically for tire pile cleanup and the amnesty program. To date, the WV DOH has successfully cleaned up all the large piles and only a few smaller sites still remain. As long as the title fee is in effect, tire cleanup efforts will also remain active.

\section{Ohio}

Ohio still has a significant effort underway to remove an estimated 19 million tires as well as the management of ongoing generation of scrap tires. While monofills are a major outlet for tires in Ohio, several smaller markets for beneficial end uses have been identified. The potential growth for TDF and whole tire consumption markets appear favorable. The Ohio Environmental Protection Agency (OEPA) recently sponsored a conference on TDF to support this market. The OEPA Division of Solid and Infectious Waste Management oversees the scrap tire program, working in conjunction with the Department of Natural Resources to foster the development of markets for recycled materials that includes scrap tires.

While there are no power generation facilities continuously using TDF in Ohio, there are industrial boilers using TDF. A significant fraction of TDF material is shipped out of state to cement kilns. Compared with other states in the region, Ohio's Scrap Tire Management Program is well defined. It requires businesses involved in transportation and processing to be registered or licensed, and utilizes shipping papers and annual reporting to track tire management and disposal activities. Licensing and registration is not likely required for those who only utilize the recycled TDF materials. This would include power generation facilities that have TDF delivered to its site by a licensed transporter. Ohio also defines the proper storage and temporary accumulation of tires, requiring storage permits for large quantities of TDF, or compliance with approved storage practices.

Please see these websites for more information on Ohio regulations: http://www.epa.state.oh.us.dsiwm/pages/tire docs.html and http://www.epa.state.oh.us.dsiwm/pages/tirepro.html.

\section{Pennsylvania}

Compared to West Virginia and Ohio, Pennsylvania has been successful in developing markets for the consumption of whole tires and TDF by other industries, such as cement 
kilns. Approximately 5 million tires are consumed as fuel annually in Pennsylvania. The Pennsylvania Department of Environmental Protection (PA DEP) oversees the management of scrap tires, and while they are classified as a municipal waste, they are managed as a residual waste to promote recycling and beneficial use. Until recently, however, transportation of tires was not tracked in Pennsylvania, resulting in abuse and illegal dumping and disposal of tires.

Today, haulers must provide reports of their activities as part of the state's oversight of the Waste Tire Recycling Program (Act 190 and Act 111) [9]. Further amendments to Act 111 and Act 190 may require licenses for processors to ensure proper handling. The retailer adds a $\$ 1$ fee to the cost of new tires for mass transit activities; an additional fee is charged for collection, hauling, and disposal. For most tire retailers, this fee is comparable to other states ( $\$ 1$ to $\$ 3$ per tire). The PA DEP receives annual funding from the state to pursue the remediation of approximately 12.5 million tires that remain throughout the state. The PA DEP has also recently established a grant program to reimburse entities involved in the establishment of waste tire collection programs.

\section{Michigan}

Michigan residents generate more than 7.5 million scrap tires each year; more than 25 million scrap tires are stored or dumped at various sites around the state. In 1991, legislation was enacted to properly manage scrap tires and prevent continued accumulation. Funding is provided by the Scrap Tire Grant Program to manage piles accumulated prior to passage of the 1991 statute. Without the public funding and access to the sites, these piles would remain a public concern long into the future. The implementation and enforcement of the legislation have resulted in the development of substantial scrap tire markets [10].

In November 1992, Hillman Power Company was issued a permit to co-fire TDF with wood to generate electricity. Hillman has continued to use TDF, and is permitted to use more than 1.46 million tires per year with a standing application to expand their capacity to two million per year. Since 1992, five other facilities have been issued TDF permits. The permit capacity of these five facilities is 12.86 million tires per year, bringing total TDF capacity in Michigan to 14.3 million scrap tires per year. In addition, TDF test burns have been completed at two potential facilities. While the permitted capacity far exceeds the annual generation rate of scrap tires by Michigan consumers, the actual use rate is somewhat less at this time. Most of the permit holders require scrap tires to be processed before delivery to their facility.

The market capacity for TDF and other approved uses now exceeds the current annual generation rate, and provides sufficient capacity to handle tires that have been accumulated within a reasonable timeframe. While permitting additional capacity could hasten the potential for cleanup of troublesome piles, it may in fact lead to scrap tire importation from nearby states and Canada. This has created controversy over subsidizing capacity beyond 16 million tires annually. While citizens in Michigan accept that the consumption of TDF in properly permitted facilities has proven to be environmentally sound, they view the importation of tires as unwanted and unnecessary. 


\section{Regulatory Considerations for Using TDF as a Supplemental Fuel}

The objective of this section is to provide an overview of the applicability of regulatory requirements for using TDF as a supplemental fuel at power generation and industrial boilers utilizing coal as their primary fuel. Relevant Federal and State environmental regulations are identified and briefly described. The first step in any permitting strategy is identifying the applicable regulations and requirements for using a supplemental fuel, which assumes that the plant exists and is already permitted. After a detailed analysis of TDF's appropriateness for a specific facility, the environmental agency must be notified of the intent or interest in 1) conducting trail period to examine performance of the unit, 2) demonstrate compliance with existing permits, and 3) pursuing the use of TDF as a supplemental fuel on a permanent basis. Although the use of TDF in small percentages and in the appropriate type of combustion system, would not result in significant environmental impacts to air, water, or land, it is still a change in the method of operation that should not be undertaken without first notifying the appropriate regulatory agency. While the intent to add TDF as an approved fuel may initiate a number of comprehensive environmental permit reviews, the most common review and potentially most cumbersome is the air permit.

A recent paper by Letheby highlights the federal environmental permits that must be amended to include the use of supplemental fuels, such as TDF [11]. While Title V permits are common for large facilities, the process for amending state permits may differ for smaller facilities.

Amending an existing permit to include the use of TDF usually requires a trial period overseen by the regulatory agency to collect data and confirm that emissions do not exceed the regulated levels. This trial period also serves as an opportunity to evaluate the other operational considerations. The details of a trial period, such as test duration, sampling plan, and permitting constraints, are unique to the facility and must be negotiated with the governing agency. The overall process for testing is straightforward. It is essential that conditions should be identified prior to executing the trial period for determining the temporary and potential long-term benefits and impacts of supplemental fuel use. Even if the testing yields no increase in existing or new emissions, the permit must be amended to include TDF material. In cases where an increase in emissions is observed, the use of TDF is usually not justified.

\section{Air Permits}

Federal regulations govern ambient air pollutant concentration levels at major stationary sources. Using TDF may require permit changes if fuel blending is considered a modification. According to the Code of Federal Regulations, “.... any physical or operational change to an existing facility which results in an increase in the emission rate to the atmosphere of any pollutant to which a standard applies shall be considered a modification," (i.e., New Source Performance Standards (NSPS) for steam generating units apply to particulate matter, sulfur dioxide, and oxides of nitrogen) $[6,12]$. 
The U.S. EPA, NSPS, and the Prevention of Significant Deterioration (PSD) regulations can be interpreted to mean that if using TDF can be achieved without installation of new material handling equipment, then the facility should not be required to comply with NSPS or PSD requirements, as long as hourly emissions do not increase, and annual emissions do not increase significantly [13]. This allows power generation facilities to obtain federal and state air permits for TDF use, provided no hourly or annual emission increases occur. However, if the facility does not include TDF as a fuel in its Title V Air Operating Permit, the permit must be modified to correct the fuel capabilities. Emission data, gathered in the form of trial periods at the plant, are used to support the permit modification.

\section{Water Permits}

The Clean Water Act (CWA) established the framework for water pollution control. One requirement of the CWA is that a permit must be obtained before any point source discharges can be made to the navigable waters of the United States. The permit program, called the National Pollutant Discharge Elimination System (NPDES), provides a method for governmental agencies to identify waste entering the nation's water supply, and to establish effluent limitations, which are tailored to protect water quality standards.

Effluent limitations were developed for various point source categories, based upon available pollution control technologies. There is no specific category of effluent limitations applicable to industrial power plants. However, the limitations and technologies promulgated for steam electric power generators have been imposed in NPDES permits for industrial power plants [14]. New NPDES permits will include limitations and prohibitions for the discharge of toxic pollutants.

At an existing facility, it becomes difficult to state with any certainty what water approvals will be required, but no new discharges are expected, since TDF would probably be stored in the vicinity of the coal pile, and storm water runoff would be treated in the same system with no expected change in effluent quality. Since no new wastewater treatment requirements are expected for co-firing TDF, it is expected that no plan approvals or NPDES permit modifications would be required from the regulatory agency.

\section{Waste Permits}

All wastes - whether discharged to air, water, or land - are covered by some section of the Resource Conservation and Recovery Act (RCRA). Depending on the nature of a particular solid waste stream, the provisions of RCRA may be extensive. Traditionally, high volume combustion wastes, such as fly ash, bottom ash, and scrubber sludge, are included in the RCRA definition of solid wastes, but are classified as a non-hazardous waste.

While trace elements in TDF vary from coal (TDF has higher zinc and iron from belt material), the bottom ash and fly ash generated from using TDF should still be designated non-hazardous. These solids can be readily and safely landfilled usually without any change to existing ash disposal practices. 
Most states require a toxicity characteristic leaching procedure (TCLP) test to determine whether solid waste may exhibit hazardous characteristics. The residual amounts of metals anticipated from using TDF are not expected to the change the waste classification of a facility's ash. This is because the amounts of zinc and iron will not be significant and are not listed in the TCLP list of hazardous trace metals. As a precautionary measure, a TCLP test may be done on the ash to confirm that no trace metals are present in appreciable quantities. The following is an abbreviated list of contaminants that are included in the TCLP test and their corresponding regulatory limit [15].

\begin{tabular}{|l|l|}
\hline Arsenic & $5.0 \mathrm{milligrams}$ per liter $(\mathrm{mg} / \mathrm{l})$ \\
\hline Barium & $100.0 \mathrm{mg} / \mathrm{l}$ \\
\hline Cadmium & $1.0 \mathrm{mg} / \mathrm{l}$ \\
\hline Chromium & $5.0 \mathrm{mg} / \mathrm{l}$ \\
\hline Lead & $5.0 \mathrm{mg} / \mathrm{l}$ \\
\hline Mercury & $0.2 \mathrm{mg} / \mathrm{l}$ \\
\hline Selenium & $1.0 \mathrm{mg} / \mathrm{l}$ \\
\hline Silver & $5.0 \mathrm{mg} / \mathrm{l}$ \\
\hline
\end{tabular}

Zinc and iron are not contaminants in determining the toxic characteristics of waste.

The use of TDF may result in an increase in the quantity of waste. The disposal of solid waste generated by the facility must comply with non-hazardous solid waste disposal rules and regulations. Once the waste quantity and characteristics are determined, the state regulatory agency should be contacted to confirm appropriate disposal methods for the facility. Again, no major changes to disposal methods are expected from using TDF as a supplemental fuel.

\section{Regional Analysis of Using TDF: Air Quality Regulatory Considerations}

Several states, including West Virginia, Ohio, and Pennsylvania classify TDF as a fuel rather than a waste product, so the processed material is not managed under their scrap tire programs once it is leaves the processor. The use of TDF by power generation and other industries is approved by air quality regulatory agencies and programs. Cocombustion of TDF must be reviewed and approved by the state, even if no increase in emissions is observed during the trial period, and no significant changes to the existing air permits are required.

In West Virginia, the terms of the trial period are negotiated with the West Virginia DEP Division of Air Quality. Approval is granted via official correspondence. The existing permit can be amended via correspondence to allow the use of TDF within a specified range, if testing shows no increase in existing permitted emissions. If modifications to equipment are required, then modification permits may also be required. West Virginia has the only power generation facility is this region permitted to use coal and TDF blended fuel. Allegheny Energy Supply Company, LLC successfully operates a 190-MW cyclone boiler that feeds coal and TDF at their Willow Island Power Station. The facility 
operates under a Federal Title V permit and State Consent Order to use TDF and biomass with coal as a mixed fuel.

Pennsylvania will also approve a trial testing period via correspondence, but only for a very short duration. Authorization to continue may be granted if testing shows no increases in any emissions. A longer duration test would likely require plan approval and a construction permit. If testing shows increases in any of the monitored pollutants, then the facility would be required to obtain a plan approval, which includes a review of the constituents, best available technologies, pollution control equipment, monitoring, and other requirements [16]. To date, Pennsylvania has granted air permits to three cement kiln plants to use TDF.

Ohio EPA has a similar process for granting a trial period, negotiated through meetings and official correspondence. OEPA requires samples of priority pollutants and may include a requirement to sample for metals, dioxins, and furans. All changes to an existing permit follows the Permit to Install process [17]. Amendments to Title V permits follow a similar process. Exemptions can be granted to facilities if no changes to air emissions, equipment, and operational parameters are required.

\section{External Influences of Using TDF}

The perception of blending TDF with coal has been varied. The public generally views TDF as a beneficial use of stockpiled tires and recognizes the benefits of proper disposal of scrap tires (non-proliferation of West Nile Virus, mosquito and rodent control, avoidance of uncontrolled infernos of tire piles, and aesthetic improvement). However, some groups have opposed the use of TDF at any level, and may also share an interest in eliminating the use of coal to produce power. One issue that may contribute to concerns with combusting TDF is that past communication efforts and literature have not successfully differentiated between controlled combustion of TDF and open tire fires. The air emission data collected from open fires has been equated to the emissions expected from engineered boiler systems equipped with post-combustion emission control devices and incorrectly represented. While the potential benefit in reducing some of the priority pollutant emissions (e.g., $\mathrm{NO}_{\mathrm{x}}$ ) from coal-fired stream and power generation systems is recognized, the interest in trace contaminants may evolve as the most vocal concern. Facilities that are considering trial periods using TDF must also consider a sampling plan for the baseline and trial period such that the data is representative and complete. While this data is important for reviewing the existing permit for the facility, it is equally important for communication purposes. The power generation facility must consider an individual approach to communicating changes at their facility, even though their operating permit may not require such activity.

\section{Conclusions}

The use of TDF as a supplemental fuel offers justifiable benefits to steam and power generation facilities if properly evaluated. Benefits include lowering fuel costs followed by a boost in efficiency and lowering of $\mathrm{NO}_{\mathrm{X}}$ and other emissions. Maximum benefit is attained when proper consideration is given to the type of TDF and the available supply 
in the region. Operational considerations for feeding TDF in acceptable boiler designs should be addressed prior to conducting an evaluation or trial period in conjunction with state and local air quality officials. An understanding of the individual state's scrap tire programs is important for ensuring supply of TDF and if registration or license are required for handling TDF. The potential issues of introducing an alternative fuel and its impact on a facility's existing permit are the primary driver for conducting a trial period, which is mandatory in most areas. This trial period should be the last step in evaluating TDF fuel prior to using it as a supplemental fuel on a continuous basis. While each power generation facility is unique and past experience with using TDF has been different at each facility, TDF has been successfully used in many different operating scenarios and continues to offer a viable and safe outlet for the millions of scrap tires generated on an annual basis.

\section{References}

1. Rubber Manufacturers Association. 2002. U.S. Scrap Tire Markets 2001. https://www.rma.org/publications/scrap tires/index.cfm?PublicationID=11106\&CFI $\underline{D=3032139 \& C F T O K E N=30352812}$ (accessed February 27, 2004).

2. Energy Information Administration. 2003. Electric Power Monthly Table 4.2. Receipts, Average Cost, and Quality of Fossil Fuels: Electric Utilities, 2001 through May 2003. http://www.eia.doe.gov/cneaf/electricity/epm/table4 2.html. (accessed February 27, 2004).

3. ASTM. 2001. Standard Practice for Use of Scrap Tire-Derived Fuel. ASTM. West Conshohocken: PA.

4. Parsons, Robert. Ed. 2001. ASHRAE Handbook Fundamentals. ISBN 1883413885.

5. Harding, N. S. 2002. "Cofiring Tire-Derived Fuel with Coal," Proceedings of the $27^{\text {th }}$ International Technical Conference on Coal utilization and Fuel Systems, March 4-7, 2002 Tampa, Fl. ISBN No. 0-932066-27-03.

6. U.S. Environmental Protection Agency. "Standards of Performance for New Stationary Sources" Code of Federal Regulation. Title 40, Part 60, Subpart A, Section 60.14 (40CFR60.14). GPO online database: http://www.gpoaccess.gov/cfr/index.html (accessed February 27, 2004).

7. U.S. Environmental Protection Agency. 1999. State Scrap Tire Programs A Quick Reference Guide: 1999 Update. Report No. EPA-530-B-99-002. www.epa.gov

8. Bell, Margie. 2002. “A Tale of Two Tire Programs," Scrap, July/August 2002. www.scrap.org.

9. Pennsylvania Department of Environmental Protection. 2004. Municipal and Residential Waste Homepage. Waste Tire Program www.dep.state.pa.us/dep/deputate/airwaste/wm/MRW/tires/tires.htm. (accessed February 27, 2004).

10. Michigan Department of Environmental Quality. 2001. Statewide Strategy To Expand The Use Of Tire-Derived Fuels. 
http://www.deq.state.mi.us/documents/deq-wmd-stp-tirefuel.pdf (accessed February 27, 2004).

11. Letheby, Kirby. 2002. "Utility Perspectives on Opportunity Fuels." Proceedings of the $27^{\text {th }}$ International Technical Conference on Coal utilization and Fuel Systems, March 4-7, 2002, Tampa, Fl. ISBN No. 0-932066-27-03.

12. U.S. Environmental Protection Agency. 2003. "Standards of Performance for Electric Utility Steam Generating Units for Which Construction is Commenced After September 18, 1978." Code of Federal Regulation. Title 40, Part 60, Subpart Da (40CFR60, Subpart Da). GPO online database:

http://www.gpoaccess.gov/cfr/index.html (accessed February 27, 2004).

13. U.S. Environmental Protection Agency. 2003. "Prevention of Significant Deterioration of Air Quality." Code of Federal Regulation. Title 40, Part 51 Subpart I Section 51.166 (40CFR51.166). GPO online database: http://www.gpoaccess.gov/cfr/index.html (accessed February 27, 2004).

14. U.S. Environmental Protection Agency. 2003. "Steam Electric Power Generating Point Source Category." Code of Federal Regulation. Title 40, Part 423 (40CFR423). GPO online database: http://www.gpoaccess.gov/cfr/index.html (accessed February 27, 2004).

15. U.S. Environmental Protection Agency. 2003. "Characteristics of Toxic Waste: Toxic Characteristics." Code of Federal Regulation, Title 40, Part x Subpart C, Section 261.24 (40CFR261.24). GPO online database: http://www.gpoaccess.gov/cfr/index.html (accessed February 27, 2004).

16. Pennsylvania Department of Environmental Protection. 2003. Guide to DEP Permits and Authorizations. Online report: www.dep.state.pa.us.

17. Permit-to-Install and Operate (PTIO) Program Webpage, Ohio Environmental Protection Agency PRogram, http://www.epa.state.oh.us/dapc/permits/ptio.html. $\mathrm{OH}$ 